\title{
Protein quality evaluation twenty years after the introduction of the protein digestibility corrected amino acid score method
}

\author{
Joyce Boye $^{1,2 *}$, Ramani Wijesinha-Bettoni ${ }^{1}$ and Barbara Burlingame ${ }^{1}$ \\ ${ }^{1}$ Nutrition and Consumer Protection Division, Food and Agriculture Organization of the United Nations, \\ Viale delle Terme di Caracalla, 00153 Rome, Italy \\ ${ }^{2}$ Food Research and Development Centre, Agriculture and Agri-Food Canada, 3600 Casavant Boul West, \\ Saint Hyacinthe, Quebec, Canada, J2S $8 E 3$ \\ (Submitted 30 August 2011 - Final revision received 17 February 2012 - Accepted 22 February 2012)
}

\section{Abstract}

In 1989 the Joint FAO/WHO Expert Consultation on Protein Quality Evaluation recommended the use of the Protein Digestibility Corrected Amino Acid Score (PDCAAS) method for evaluating protein quality. In calculating PDCAAS, the limiting amino acid score (i.e., ratio of first limiting amino acid in a gram of target food to that in a reference protein or requirement) is multiplied by protein digestibility. The PDCAAS method has now been in use for 20 years. Research emerging during this time has provided useful data on various aspects of protein quality evaluation that has made a review of the current methods used in assessing protein quality necessary. This paper provides an overview of the use of the PDCAAS method as compared to other methods and addresses some of the key challenges that remain in regards to protein quality evaluation. Furthermore, specific factors influencing protein quality including the effects of processing conditions and preparation methods are presented. Protein quality evaluation methods and recommended protein intakes currently used in different countries vis-à-vis the WHO/FAO/UNU standards are further provided. As foods are frequently consumed in complement with other foods, the significance of the PDCAAS of single protein sources may not be evident, thus, protein quality of some key food groups and challenges surrounding the calculation of the amino acid score for dietary protein mixtures are further discussed. As results from new research emerge, recommendations may need to be updated or revised to maintain relevance of methods used in calculating protein quality.

Key words: Protein Quality: Amino Acid: Protein Digestibility Corrected Amino Acid Score: PDCAAS

\section{Introduction}

Proteins are important components of the human diet and play an essential role as structural and functional components of living systems. Food proteins provide amino acids (AA) which serve as building blocks of all vital organs, muscles (including heart muscles), hormones and biological fluids such as blood. As the human body is incapable of maintaining reserves of protein, a constant supply of good quality protein is needed to maintain growth and other physiological functions. Insufficient intake of protein especially during periods of growth and development can affect all organs in the body including the brain, heart, immune system, and other vital organs. Protein quality of foods is, therefore, an important criterion for the provision of adequate nutrition and maintenance of good health.

A significant effort has been made in the last several decades to establish methods for evaluating protein quality. The 1957 FAO Committee report on Protein Requirements ${ }^{(1)}$ recommended the use of a reference protein with an "ideal" AA composition to define the pattern of human AA requirements. In 1963, a Joint FAO/WHO Expert Group ${ }^{(2)}$ further discussed the need to take into consideration the rate of obligatory nitrogen loss from the body on a protein-free diet when determining human protein requirements. Discrepancies between the obligatory nitrogen loss and the minimum nitrogen intake needed to ensure balance, were considered by an Ad Hoc Expert Committee convened in $1971^{(3)}$. The concern was that even for proteins with a high biological value, higher amounts of protein were required than that indicated by the obligatory nitrogen loss. The committee also recommended a safe level of intake for a population, which was defined as the average protein requirement of the individuals in the population plus 1.96 times the standard deviation (SD). A follow-up Joint FAO/WHO/UNU Expert Consultation on Energy and Protein Requirements in $1981^{(4)}$ emphasised the need to consider digestibility in the evaluation of protein quality. Eight years later, the Joint FAO/WHO Expert Consultation on Protein Quality Evaluation ${ }^{(5)}$ recommended the use of the Protein Digestibility Corrected Amino Acid Score (PDCAAS) method for protein quality evaluation. The PDCAAS method has now been in use for 20 years. The 2007 report of the 
FAO/WHO/UNU Expert Consultation on protein and AA requirements in human nutrition ${ }^{(6)}$ highlighted several aspects of protein quality that still required consideration. The report also provided new reference patterns based on AA requirements for different age groups.

The current paper provides a review of the use of the PDCAAS method compared to other methods for evaluating protein quality and addresses some of the key challenges that remain in regards to protein quality evaluation. A brief overview of human AA and protein requirements and factors influencing dietary protein quality is provided, as well as a summary of the progress made by the international science community to identify acceptable methods for evaluating protein quality. Current recommendations for protein intake are also reviewed and specific examples of standards and requirements used in a few selected countries vis-à-vis the WHO/FAO/UNU standards are presented.

\section{Human amino acid and protein requirements}

Proteins are made up of amino acids linked by peptide bonds and are the main supply of nitrogen in the diet. To sustain bodily functions and growth, humans require certain minimal levels of protein intake as well as adequate supplies of dietary essential amino acids that are not synthesized by the body. The aim of protein quality evaluation is to determine the ability of a protein to meet maintenance needs plus special needs for growth, pregnancy, or lactation ${ }^{(7)}$. For most adults, protein intake should be in equilibrium with protein loss. Positive protein balance is, however, required for growing infants and children and during pregnancy and lactation, and requirements may also increase during times of illness and recovery.

Nitrogen balance in humans, which is a measure of daily nitrogen intake minus nitrogen excreted, is a reflection of both protein and energy intake from the diet. Protein nutritional requirement is, therefore, defined as the lowest level of dietary protein intake that will balance the losses of nitrogen from the body, and thus maintain the body protein mass (i.e., in persons at energy balance with modest levels of physical activity) ${ }^{(6,7)}$. In children or pregnant/lactating women, this further includes needs associated with the deposition of tissues or the secretion of milk at rates consistent with good health.

\section{Factors influencing dietary protein quality}

Protein quality may be defined as the ability of a food protein to meet the body's metabolic demand for amino acids and $\mathrm{N}$ and is determined by the AA composition and digestibility of the protein as well as the bioavailability of the individual AA. The term is relative allowing a comparison of the adequacy of different sources of food proteins to meet human protein requirements. Both digestibility and bioavailability are affected by the food matrix (e.g., levels and types of fat, carbohydrate and antinutritional compounds). Other factors influencing protein quality are demands that are specific to the individual consuming the food, such as age, health status, physiological status and energy balance ${ }^{(7)}$.

\section{Amino acid composition}

Amino acids are classified into those which cannot be synthesized by the body and therefore must be obtained by the diet, "indispensable" (IAA) or "essential" (EAA) (His, Ile, Leu, Lys, Met, Phe, Thr, Trp and Val), and those which the body can produce, "dispensable" or "nonessential" (Asp, Asn, Glu, Ala, Ser, Cys, Tyr, Gly, Arg, Gln, Pro). However, these two categories are not absolute or mutually exclusive: the endogenous capacity for the formation of some dispensable AA may not always meet demand and, potentially, some de novo synthesis of IAA may occur following urea salvage in the lower gut $^{(6)}$. Some AA, such as Cys, Tyr, Gly, Arg, Gln, Pro and taurine, are termed "conditionally indispensable", as they become dietary essential only under specific pathological or physiological conditions.

The 2007 WHO/FAO/UN Expert Consultation on proteins ${ }^{(6)}$ stressed the need to interpret these classifications with care, as there appears to be an absolute metabolic need for both dispensable and indispensable AA. The efficiency of utilization of IAA is dependent on the total $\mathrm{N}$ and the form of $\mathrm{N}$ in the diet. The higher the dietary total $\mathrm{N}$, the lower the amount of IAA needed to achieve N-balance ${ }^{(6)}$. The report further states that when all or any of the IAA are present in excess of demand, the absorbed mixture is unbalanced and limited by dispensable AA, which would need to be supplied from oxidation of surplus IAA. However, the biological value of a protein is defined in terms of how well the profile of IAA in a protein matches that of the pattern required by body. Some authors have argued that IAA are important at higher intakes than those in the requirement pattern, especially in the case of high quality proteins (e.g. egg, milk, fish and meat protein products) that are used to supplement other low quality proteins ${ }^{(8)}$. Another argument supporting higher intakes of IAA is that their role extends beyond that of supporting growth or $\mathrm{N}$ balance (i.e., implications in such diverse functions as lean body mass retention, cell signalling, bone health, glucose homeostasis and satiety induction $)^{(7)}$.

\section{Protein digestibility}

In order for constituent AA to be released, proteins must first be digested. A possible exception is in neonates where some uptake of intact proteins or peptides from the intestinal lumen into the systemic circulation can occur. Digestibility is usually defined in terms of the balance of AA across the small intestine (mouth to terminal ileum: ileal digestibility), or across the entire gut (mouth to anus: faecal digestibility), based on the principle that the difference between intake and losses provides a measure of the extent of digestion and absorption of food protein as AA by the gastrointestinal tract for use by the body ${ }^{(6)}$. This net balance across the digestive tract is a complex process that involves considerable exchange of nitrogen in terms of protein, AA and urea between systemic pools and the gut lumen ${ }^{(6)}$. Large differences can occur between the digestibility of a protein and specific AA, especially where antinutritional factors are present, such as in uncooked cereals and legumes ${ }^{(9)}$. 
The digestive process starts with hydration and solubilization in the mouth. Most food proteins remain intact until reaching the stomach. A range of different proteolytic enzymes (some specific to certain AA) are necessary to break the peptide bonds within the protein chain. $\mathrm{HCl}$ in the stomach denatures some proteins, making the peptide bonds more accessible for proteolysis by digestive enzymes. The $\mathrm{HCl}$ also converts the pepsinogen secreted by the stomach to the active protease pepsin, which cleaves the protein into peptide fragments. The pancreas secretes enzymes such as trypsin, chymotrypsin, carboxypeptidases, collagenase and elastase into the duodenum, and these enzymes break up the peptides into smaller peptide fragments. The final digestion occurs in the small intestine by enzymes such as aminopeptidases and tripeptidases, which split the remaining short peptide fragments into single $\mathrm{AA}$ or di- and tri-peptides, which can be absorbed by the intestinal mucosal cells. Undigested and unabsorbed nitrogenous residues are then transported to the large intestine (colon) where further microbial modifications of this material are possible within the large intestine, prior to faecal excretion.

\section{Bioavailability of amino acids}

The bioavailability of an amino acid is the proportion of ingested dietary AA that is absorbed in a chemical form suitable for it to be utilized for protein synthesis or metabolism $^{(6,10)}$. There is no direct method for measuring bioavailability and it is, therefore, generally estimated using measures of in-vivo digestibility or determined using sloperatio assays, which give the bioavailability relative to a reference $\operatorname{protein}^{(10)}$

The utilization of an amino acid may be influenced by ingredient characteristics, genetics, physiological state and dietary factors $^{(11)}$. Food processing can sometimes reduce the bioavailability of AA. One common example is Lys which has undergone Maillard reactions with reducing sugars or other aldehyde compounds during heat processing such as in heated skim milk powder ${ }^{(9)}$ : although it can be digested and partially absorbed by the body, it cannot be utilized for protein synthesis. Other changes associated with alkaline and/or heat processing include racemization of L-amino acids, and the formation of crosslinked peptide chains such as lysinoalanine, which result in a loss of Lys, Cys and Thr, together with reduced protein digestibility ${ }^{(8,9)}$. Antinutritional factors can also cause a reduction in protein bioavailability. Some workers, therefore, suggest that digestibility as determined traditionally may not be a good approximation of bioavailability in products containing antinutritional factors present naturally or formed during processing or storage ${ }^{(9)}$.

\section{Overview of methods used for evaluating protein quality}

A list of some of the principal methods used in evaluating protein quality is provided in Table 1 , along with some considerations on their appropriateness and effectiveness. Methods frequently used include amino acid score (AAS), nitrogen balance (NB), in vivo protein digestibility (apparent, corrected or true), in vitro protein digestibility, protein efficiency ratio (PER), estimated PER, maximum PER, net protein ratio (or retention) (NPR), protein rating (PR), net protein utilization (NPU), biological value (BV) (apparent, true, relative) and the PDCAAS. Details on these different methodologies and their use have been extensively reported in the literature.

AAS is the ratio of the amino acid content in $1 \mathrm{~g}$ of a target protein to that of a reference protein or requirement. AA analysis, which is typically undertaken using ion exchange chromatography (IEC), gas chromatography (GC) or reverse phase high performance liquid chromatography (HPLC), is needed for calculating the amino acid content. A standard procedure for AA analysis was recommended by the 1989 Joint FAO/WHO Expert Consultation. This is because data can vary markedly depending on the method and conditions used. The WHO/FAO/UNU Expert Committee ${ }^{(6)}$ suggested that since in practice dietary proteins are likely to be limited only by Lys (most cereal proteins), the sulphur AA (legume proteins), Trp (some cereals such as maize) or Thr (some cereals), in calculating scores it is usually only necessary to use a pattern based on these four AA. In addition to variations in results if not properly calculated, major issues regarding the use of amino acid score include lack of information on AA bioavailability. Furthermore, processing can modify IAA which can influence digestibility. Additionally, the degree of amino acid absorption may depend on the length of peptide released after hydrolysis (limit peptides).

Nitrogen balance provides a measure of body nitrogen retention based on directly measuring daily nitrogen intake minus nitrogen excreted. Digestibility measurements estimate the extent to which proteins are hydrolysed by gastrointestinal enzymes into AA, and the extent to which these AA are absorbed, and provide a measure of the dietary protein intake which is made available to the organism after digestion and absorption. Protein efficiency ratio measures the ability of a protein to support the growth of young growing rats and is reported as the gain in weight per gram of protein consumed. As has been discussed extensively in the literature, rats have a higher need for sulphur containing IAA, thus, the PER method overestimates the requirements for humans and likely underestimates the quality of some proteins, especially plant proteins. NPR is similar to PER except that an additional factor (average weight loss of rats fed a non-protein diet) is taken into consideration. Protein rating is the product of the PER of a protein multiplied by the amount of protein in a reasonable daily intake. NPU provides a measure of overall protein utilization and reflects the proportion of ingested protein retained. Biological value, on the other hand, provides a measure of how well the absorbed amino acid profile matches that of the requirement. Challenges associated with BV include the following: results for the same food vary significantly depending on $\mathrm{N}$ intake; results for different foods may be similar at low $\mathrm{N}$ intake and very different at higher intake levels; proteins which are completely devoid of one IAA can still have a BV of up to $40 \%$; the method ignores the importance of factors which influence digestion of the protein 
Table 1. List of some of the principal methods used in evaluating dietary protein quality

\begin{tabular}{l} 
Protein Quality Evaluation \\
Method \\
\hline Amino Acid Score \\
Apparent Protein Digestibility \\
Corrected Protein Digestibility \\
(also sometimes called True \\
Protein Digestibility) \\
In vitro Protein Digestibility
\end{tabular}

Abbrev

Method Summary and/or Equation

AAS $=\mathrm{mg}$ of limiting amino acid in $1 \mathrm{~g}$ test protein $/ \mathrm{mg}$ of limiting amino acid in a reference protein or requirement pattern

Nitrogen Balance

APD

CPD (TD)

NB

Protein Efficiency Ratio

Estimated Protein Efficiency Ratio

Maximum Protein Efficiency Ratio

Net Protein Ratio (or retention)

Net Protein Utilization ${ }^{\mathrm{b}}$

Protein Rating

Relative Nutritive Value

Apparent Biological Value

True Biological Value

PERmax
$\mathrm{APD}=100[($ Protein intake - Faecal protein $) /$ Protein intake $]$ In vivo method

$\mathrm{CPD}$ or $\mathrm{TD}=100[($ Protein intake $-($ Faecal protein - metabolic faecal protein

In vivo method

IVPD $=210 \cdot 46-18 \cdot 10 X$

where, $X=p H$ of sample suspension (during hydrolysis) at

$10 \mathrm{~min}$.

$N B=$ Nitrogen intake $(N I)-$ nitrogen losses $(N L)$

PER - Gain in weight of rat per gram of protein eaten $P E R=$ Gain in body mass $(g) /$ Protein intake $(g)$

Protein efficiency ratio (PER) is estimated using a regression equation

$e P E R=0.468+0.454($ Leu $)-0.105(T y r)$

(the optimum dietary protein dmn level

$P E R=$ Gain in body mass $(g) /$ Protein intake $(g)$

$\mathrm{NPR}=$ (weight gain of test rat + weight loss of non-protein rat)/ (protein consumed by test rat)

of ingested protein retained

$N P U=((0.16 \times(24$ hour protein intake in grams $))-((24$ hour urinary urea nitrogen $)+2)-(0.1 \times$ (ideal body weight in kilo$\mathrm{P}=$ Protein in a reasonable daily intake $\mathrm{x}$ PER

efficiency of extraction of

nutrients during digestion (digestibility).

Proportion of the absorbed nitrogen retained

$B V^{c}=\left[\left(N_{i}-N_{e(f)}-N_{e(u)}\right) /\left(N i-N_{e(f)}\right)\right] \times 100$

Proportion of the absorbed nitrogen retained taking into consider-

ation the metabolic nitrogen loss

$B V^{c}=\left[\left(N_{i}-\left(N_{e(f)}-N_{e p f(f)}\right)-\left(N_{e(u)}-N_{e p f(u)}\right)\right) /\left(N i-\left(N_{e(f)}\right.\right.\right.$

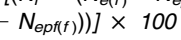

rBV Biological value of a food source relative to egg

$\left(B V_{(\text {test })} / B V_{(e g g)}\right) \times 100$
Issues

Reference

- Does not provide information on bioavailability of IAA.

(5)

- Processing can modify structure of AA.

- Amino acid absorption will potentially depend on length of peptide

released after hydrolysis which is not accounted for.

- Does not take into consideration concentration and availability of IAA. (9)

- Does not account for metabolic faecal protein.

- Does not take into consideration concentration and availability of IAA.

- Does not measure true digestibility (i.e., digestibility is calculated).

- Does not take into consideration concentration and availability of IAA.

- Large pool of urea in body water means that there is an extended delay before any change in nitrogen input or output becomes fully apparent.

- An arbitary adjustment factor ${ }^{e}$ sometimes used in calculation

- Underestimation of actual minimum physiological needs.

- Rats have a higher requirement than humans for some amino acids.

- Does not properly credit protein used for maintenance purposes.

- Gain in body weight does not necessarily correspond to gain in body protein.

- PER values vary with levels of protein intake.

- Poor precision and reproducibility

- Does not measure true protein efficiency (i.e., PER is calculated).

- Same issues as for PER except determined at optimal dietary protein intake.

(5), and references therein;

(6)

(5), and references therein

\section{- Same issues as for PER}

- Measured when protein content of diet is below that of requirement and may not be appropriate when diet is adequate.

- Same limitations as for PER.

- Similar issues as for NB, PER, etc.

- Method becomes limited in samples severely lacking in Lys.

- Does not take into consideration metabolic nitrogen loss.

- Ignores variation in digestibility of a food (i.e., ignores the importance of factors which influence digestion of the protein and interaction of protein with other dietary factors before absorption).

- Measured when protein content of diet is below that of requirement and may not be appropriate when diet is adequate.

- BV results for the same food varies significantly depending on $\mathrm{N}$

intake.

- BV results for different foods may be similar at low $\mathrm{N}$ intake and very different at higher intake levels.

- Proteins which are completely devoid of one IAA can still have a BV of up to 40.

- Same limitations as for BV above. Additionally, due to differences in $\mathrm{BV}$ at different $\mathrm{N}$ intakes, proportionately between proteins seen at 


\section{N British Journal of Nutrition}

Table 1. Continued

Protein Quality Evaluation

Abbrev

Method Summary and/or Equation

Unit

Issues

Reference

Protein Digestibility Corrected

PDCAAS

Relies on determination of protein contents, amino acid profile and
protein digestibility

$\%$ or dmnl

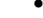

- Proteins with higher than $100 \%$ scores are rounded off to $100 \%$ (additional benefit in complementing less nutritious proteins is not

$(5,6,8,9,86)$, and

PDCAAS $=((m g$ of limiting amino acid in $1 \mathrm{~g}$ of test protein $) /(\mathrm{mg}$ of same amino acid in $1 \mathrm{~g}$ of reference protein or requirement pattern)) $\times$ true faecal digestibility $(\%) \times 100$

- Does not include impact of anti-nutritional factors associated with protherein

teins, including naturally occurring and those formed during

processing, on protein digestibility and quality.

- There may be a need to include corrections for the bioavailability of

individual amino acids and not just for digestibility of protein.

- Ileal vs faecal protein/amino acid digestibility (i.e., faecal digestibility

may overestimate due to microbial degradation).

- No standardized methods available for ileal digestibility.

- Effect of age on faecal and ileal protein/amino acid digestibility is no

known.

Validity of the preschool-age child amino acid requirement values

(there is still a need for validation of the scoring pattern used for the preschool-age child). Scoring pattern does not include conditionally

IAA.

Humans consume proteins from varied protein sources. PDCAAS values of single protein sources may not have practical significance.

${ }^{\text {a }}$ Corrected for metabolic faecal protein loss

${ }^{\mathrm{b}} \mathrm{NPUstandardized} \mathrm{and} \mathrm{NPUoperative} \mathrm{distinguish} \mathrm{between} \mathrm{studies} \mathrm{at} \mathrm{fixed} \mathrm{or} \mathrm{varying} \mathrm{dietary} \mathrm{protein} \mathrm{concentrations,} \mathrm{(WHO/FAO/UNU,} \mathrm{2007)}$

${ }^{\mathrm{c}} \mathrm{BV}$ equation (definitions):

$N_{i}=$ nitrogen intake in proteins on the test diet

$N_{e(f)}=$ nitrogen excreted in faeces whilst on the test diet

$N_{e(\omega)}=$ nitrogen excreted in urine whilst on the test diet

$N_{\text {epf(f) }}=$ nitrogen excreted in faeces whilst on a protein free diet

$N_{\text {epf( })}=$ nitrogen excreted in urine whilst on a protein free diet

${ }^{d}$ dmnl - dimensionless

${ }^{\mathrm{e}}$ Example of an NB Equation using an arbitrary adjustment factor

$N I=$ Protein intake $(g /$ day $) / 6.25$

$N L=$ Urinary urea nitrogen $(\mathrm{g} / \mathrm{day})^{1}+2$ to $4^{2}$

'Obtained from $24 \mathrm{~h}$ urine sample; ${ }^{2}$ Additional arbitary adjustment factor to account for other nitrogen losses (e.g., faecal, dermal, miscellaneous and non-urea nitrogen) 
and interaction of protein with other dietary factors before absorption.

The PDCAAS method is based on a determination of protein content, amino acid profile and protein digestibility. The limiting amino acid score (i.e., ratio of first limiting amino acid in $1 \mathrm{~g}$ of protein from the target food to that found in a reference protein or reference requirement) is multiplied by protein digestibility (true faecal digestibility) which gives a value for protein quality corrected for digestibility. The first limiting amino acid is the IAA present at the lowest concentration in a food. Depending on concentration, other IAA may be described as the second, third, fourth, (etc.), limiting amino acid. The recommended reference protein for infants under 1 year of age is that of human $\mathrm{milk}^{(4)}$. For all other age groups, the FAO/WHO 1991 report recommended the use of the amino acid scoring pattern for preschool children in the 2-5 year range. The $2007 \mathrm{WHO} / \mathrm{FAO} / \mathrm{UNU}$ report, however, revised this recommendation and has suggested the use of the amino acid scoring pattern for preschool children in the 1-2 year range for preschool children, and the 3-10 $\mathrm{yr}$ pattern when judging protein quality for schoolchildren and adolescents.

\section{Effects of bioactive compounds, preparation and processing conditions on protein quality}

Protein quality of foods is affected by methods used in food preparation and processing and the presence of bioactive compounds. Foods are rarely consumed raw in today's fast paced society, and are often processed to increase convenience and safety, extend shelf life and improve taste. The quality of protein from both animal and plant sources is thus of most interest after preparation and processing. Plant-based foods are particularly of interest in this regard as they contain bioactives which in the unprocessed form can reduce digestibility and hence protein quality. Processing technologies could, however, help to transform raw grains into useful products which maximise their inherent nutritional value to ensure the nutrient security of populations, particularly, in developing countries ${ }^{(12)}$. The impacts on protein quality of bioactive compounds and some of the principal techniques used in food preparation and processing are provided below.

\section{Bioactive compounds}

Antinutritional factors (ANF) can be naturally present in the food matrix in which a protein is consumed, or be formed during processing or storage. ANF can affect both the digestibility and bioavailability of protein and AA. Examples of naturally occurring ANF include phytates in cereals and oilseeds, polyphenols in pulses, gossypol in cottonseed protein products and glucosinolates in mustard and rapeseed proteins ${ }^{(8)}$. The limited digestibility of legume proteins has been ascribed to the presence of ANF such as protease, trypsin and amylase inhibitors (which can interact with digestive enzymes to form inactive complexes), tannins (that have a high affinity for Pro and His in proteins), lectins, phytic acid (which can form complexes with proteins, proteases and amylases, inhibiting proteolysis) and non-starch polysaccharides ${ }^{(13,14)}$.

Processing methods such as soaking, cooking and fermentation have been shown to lead to better AA digestibility, most likely due to a reduction in ANF such as heat labile protease inhibitors $^{(15)}$.

\section{Germination}

Sprouting of seeds which involves soaking seeds until germination, is used in many countries as part of food preparation. Germination significantly increases protein content and decreases starch level in bambara groundnut (Voandzeia subterranea) ${ }^{(16)}$. Compared to other cooking methods (wet cooking and dry roasting), germination for 4-6 days significantly decreased phytic acid content and increased in vitro protein digestibility. The improvement of protein digestibility after germination was attributed to a reduction of polyphenols and phytic acid in the germinated seedling and an increase in soluble proteins due to the action of proteolytic enzymes. These enzymes were also effective in hydrolyzing proteinpolyphenol complexes in the seed.

Kannan et al. ${ }^{(17)}$ also reported that germination increased true protein digestibility (TPD) of cooked black bean products, however, the increase was not accompanied by an increase in PDCAAS due to the limiting amino acid score. Highest TPD and PDCAAS values were obtained for cooked germinated beans combined with rice. Germination also had little effect on the amino acid profile of cowpeas ${ }^{(18)}$. However, in vitro protein quality and starch digestibility improved after germination, resulting in a higher PDCAAS (still low) for a weaning food prepared from $24 \mathrm{~h}$ germinated cowpea flour (56\%) compared to the control cowpea flour weaning food $(47 \%)$.

In other studies, germination promoted an increase of $21 \%$ in the protein digestibility of sorghum proteins and an increase in protein extractability ${ }^{(19)}$. Protein content of mungbean, chickpea and cowpea also increased by 9-11, 11-16 and $8-11 \%$, respectively after germination, and in vitro protein digestibility similarly increased by $15-25,6-17$ and $6-17 \%$, respectively with higher improvements observed with longer times of germination ${ }^{(12)}$.

Higher increases in in vitro digestibility of Indian bean (Dolichos lablab. var. lignosus) seeds in the early stage of germination were also reported ${ }^{(20)}$. PER values increased in rats fed with the germinated bean, reaching comparable values with a control group maintained on a casein diet after $32 \mathrm{~h}$ of germination. Diets with germinated bean protein also showed marked increases in both true and apparent nitrogen digestibility, although the values were less than that observed for casein fed rats.

In addition to protein, germination also caused significant increases in thiamine, in vitro iron and calcium bioavailability and in vitro protein digestibility of green gram (Phaseolus aureus), cowpea (Vigna catjang), lentil (Lens culinaris) and chickpea (Cicer arietinum) ${ }^{(21)}$. Dehulling the germinated legumes yielded further increases in nutritive value. Phytic acid and tannin were reduced by $18-21 \%$ and $20-38 \%$, 
respectively, on germination and further reduction was observed on dehulling. The low levels of phytic acid and tannin detectable in the cotyledons after dehulling, suggest that most of the phytic acid and tannin were present in the seed coat. Negative correlations were, however, reported between antinutritional factors and nutrient bioavailability and digestibility.

Osman $^{(22)}$, however, noted that germination significantly increased tannin content in another legume (Dolichos lablab bean [Lablab purpuresus ( $L$ ) sweet]) compared with other traditional methods of food preparation, although germination was more effective in improving protein digestibility than soaking and cooking. Similarly, germination of kidney bean (Phaseolus vulgaris L.) was less effective in reducing trypsin inhibitors, saponins and phytohaemagglutinins than cooking/ autoclaving ${ }^{(23)}$. Germination, however, reduced stachyose, raffinose, phytic acid and tannins. The combination of germination followed by autoclaving resulted in a $100 \%$ reduction of phytic acid and tannin and a 9-18\% increase in in vitro protein digestibility.

\section{Wet or moist thermal treatment}

In plant proteins heat processing, especially moist heat, may sometimes improve protein digestibility by destroying protease inhibitors and denaturing proteins, which can open up their structure allowing gastrointestinal enzymes greater access for hydrolysis. Soaking, boiling, microwave cooking and autoclaving increased total IAA content determined in the seeds of cowpea, pea and kidney bean ${ }^{(15)}$. The magnitude of the effect was in the following order: autoclaving $>$ boiling $>$ microwave cooking $>$ soaking. The determined level of sulphur AA also slightly increased in all samples after microwave cooking and autoclaving, and autoclaving was found to be most effective for improving protein efficiency ratio and amino acid score (based on assumption of Cys+ Met as being first limiting), followed by micronization, microwave cooking and fermentation. In vitro protein digestibility also significantly improved after soaking, boiling, microwave cooking, pressure cooking (autoclaving) and fermentation (Table 2). The PDCAAS decreased in the order microwave cooking $>$ autoclaving $>$ boiling $>$ soaking, with some

Table 2. Effects of processing conditions on protein quality (adapted from Khattab et al. ${ }^{(15)}$ )

\begin{tabular}{|c|c|c|c|c|c|c|}
\hline \multirow{2}{*}{ Processing condition } & \multicolumn{6}{|c|}{ Legume $^{\mathrm{a}}$} \\
\hline & $\mathrm{CC}$ & EC & $\mathrm{CK}$ & EK & $\mathrm{CP}$ & EP \\
\hline \multicolumn{7}{|l|}{ Raw } \\
\hline Minimum AAS & 68.5 & 91.9 & $52 \cdot 7$ & $76 \cdot 9$ & $75 \cdot 0$ & $57 \cdot 3$ \\
\hline IVPD $^{c}$ & $82 \cdot 3$ & $81 \cdot 6$ & $70 \cdot 5$ & $78 \cdot 0$ & 78.4 & $80 \cdot 1$ \\
\hline PDCAAS $^{d}$ & 56 & 75 & 37 & 60 & 59 & 46 \\
\hline \multicolumn{7}{|l|}{ Soaking } \\
\hline Minimum AAS & $53 \cdot 1$ & $73 \cdot 8$ & 51.9 & $81 \cdot 2$ & $52 \cdot 7$ & 75.4 \\
\hline IVPD & 87.5 & $86 \cdot 7$ & $76 \cdot 0$ & 83.2 & 83.7 & $85 \cdot 5$ \\
\hline $\begin{array}{l}\text { PDCAAS } \\
\text { Boiling }\end{array}$ & 46 & 64 & 39 & 68 & 44 & 64 \\
\hline Minimum AAS & $82 \cdot 3$ & $79 \cdot 2$ & $76 \cdot 5$ & 65.4 & $70 \cdot 8$ & 71.5 \\
\hline IVPD & $98 \cdot 1$ & $97 \cdot 2$ & $87 \cdot 4$ & $94 \cdot 2$ & $94 \cdot 3$ & $95 \cdot 8$ \\
\hline $\begin{array}{l}\text { PDCAAS } \\
\text { Roasting }\end{array}$ & 81 & 77 & 67 & 62 & 67 & 69 \\
\hline \multicolumn{7}{|l|}{ Roasting } \\
\hline Minimum AAS & 83.8 & $75 \cdot 4$ & $66 \cdot 5$ & $65 \cdot 0$ & $68 \cdot 1$ & $58 \cdot 8$ \\
\hline IVPD & $77 \cdot 6$ & $76 \cdot 6$ & 64.9 & $73 \cdot 0$ & $73 \cdot 1$ & $75 \cdot 0$ \\
\hline \multicolumn{7}{|l|}{ Autoclaving } \\
\hline Minimum AAS & $65 \cdot 8$ & $108 \cdot 1$ & $90 \cdot 4$ & 89.2 & $85 \cdot 4$ & $76 \cdot 2$ \\
\hline IVPD & $90 \cdot 3$ & 89.7 & $79 \cdot 0$ & $86 \cdot 1$ & $86 \cdot 6$ & 88.3 \\
\hline \multicolumn{7}{|l|}{ Microwave } \\
\hline Minimum AAS & 94.2 & $91 \cdot 2$ & $91 \cdot 2$ & $72 \cdot 3$ & 94.2 & $100 \cdot 6$ \\
\hline IVPD & 92.8 & $92 \cdot 2$ & $81 \cdot 7$ & $88 \cdot 6$ & 89.1 & 90.9 \\
\hline PDCAAS & 87 & 84 & 74 & 64 & 84 & 92 \\
\hline \multicolumn{7}{|l|}{ Fermentation } \\
\hline Minimum AAS & $79 \cdot 6$ & $96 \cdot 2$ & $67 \cdot 6$ & $100 \cdot 0$ & $88 \cdot 8$ & 98.5 \\
\hline IVPD & $85 \cdot 1$ & $84 \cdot 3$ & 73.4 & 80.9 & 81.4 & 82.9 \\
\hline $\begin{array}{l}\text { PDCAAS } \\
\text { Micronization }\end{array}$ & Micronization & 81 & 50 & 81 & 72 & 82 \\
\hline Minimum AAS & 98.5 & $100 \cdot 0$ & $99 \cdot 2$ & 88.5 & 101.9 & $110 \cdot 8$ \\
\hline IVPD & $80 \cdot 0$ & $79 \cdot 1$ & 67.9 & 75.5 & $76 \cdot 0$ & 77.9 \\
\hline PDCAAS & 79 & 79 & 67 & 67 & 77 & 86 \\
\hline Min PDCAAS & 46 & 58 & 37 & 47 & 44 & 44 \\
\hline Max PDCAAS ${ }^{f}$ & 87 & 97 & 74 & 81 & 84 & 92 \\
\hline
\end{tabular}

${ }^{a}$ CC: Canadian cowpea; EC: Egyptian cowpea; CK: Canadian kidney bean; EK: Egyptian kidney bean; CP: Canadian pea; EP: Egyptian pea.

${ }^{b}$ AAS: amino acid score.

${ }^{\mathrm{c}}$ In vitro protein digestibility (IVPD) (\%).

d PDCAAS: protein digestibility corrected amino acid score.

${ }^{e}$ Minimum PDCAAS value obtained for a particular legume.

${ }^{\mathrm{f}}$ Maximum PDCAAS value obtained for a particular legume. 
exceptions. Very large differences in PDCAAS were observed depending on processing: for example, the PDCAAS of raw Canadian kidney beans was half the value of the PDCAAS from microwave cooking.

Saleh and El-Adawy ${ }^{(24)}$ similarly reported significant decreases in antinutritional factors (trypsin inhibitor, haemagglutinin activity, tannins, saponins and phytic acid) of chickpea (Cicer arietinum L.) after cooking (i.e., using microwave cooking and other traditional cooking methods). In vitro protein digestibility (IVPD) and protein efficiency ratio were improved by all cooking treatments from $84 \%$ (raw) to approximately $90 \%$ for IVPD and 2.3 (raw) to approximately 2.5 for PER. Chemical score and the amino acid determined to be first limiting for chickpeas subjected to the various cooking treatments, however, varied considerably, depending on the type of treatment.

In other studies, saponins, trypsin inhibitors and phytohaemagglutinins, diminished dramatically to undetectable amounts when kidney beans (Phaseolus vulgaris L.) were cooked or autoclaved $^{(23)}$. Similarly, cooking of pre-soaked seed was found to be the most effective method for reducing trypsin inhibitor activity in Dolichos lablab bean ${ }^{(22)}$ and a significant increase in IVPD was also found when raw sprouts of mungbean, chickpea and cowpea were subjected to pressure cooking and microwaving ${ }^{(12)}$.

Heat treatment can sometimes, however, be detrimental to protein quality. As an example, digestibility and extractability of sorghum proteins decreases, especially, on wet cooking ${ }^{(19,25)}$. This occurs due to binding of the tannins to proteins in tannin-containing sorghum cultivars. Tannins have antioxidant properties and are bacteriostatic and/or bactericidal for many bacteria species ${ }^{(26)}$. Although the positive benefits of tannins are increasingly being recognised, their presence in high amounts in plant based foods unfortunately has a detrimental effect on protein quality. The reduced digestibility of cooked sorghum products has also been attributed to disulphide crosslinks occurring between $\gamma$ - and $\beta$-kafirin proteins at the protein body periphery, which may impede digestion of the centrally located major storage protein, $\alpha$-kafirin ${ }^{(25)}$.

Milk sterilization (at $110-120^{\circ} \mathrm{C}, 20-30 \mathrm{~min}$ ) also causes a decline in protein quality, due to a decrease in Lys, Met and Cys ${ }^{(27)}$. Maillard reactions involving Lys, and destruction of the sulphonic group in the case of Met and Cys due to sterilization, may be the cause. PDCAAS for sterilized semi-skimmed milk was $34 \%$ whereas it was much higher for pasteurized semi-skimmed milk (76\%). In general, no appreciable Maillard reaction is expected to occur during pasteurization, and only very small losses of Lys have been reported ranging from $0-5 \%$ on ultra high temperature (UHT) treatment ${ }^{(28)}$.

In another study where hot water $\left(80^{\circ} \mathrm{C}\right)$ reconstituted powdered infant formulas were sterilized by autoclaving for $5 \mathrm{~min}$ at $105^{\circ} \mathrm{C}$, a $20 \%$ reduction in total protein was found after autoclaving compared with the conventional preparation, where samples were reconstituted with warm water $\left(37^{\circ} \mathrm{C}\right)$ in glass bottles but not autoclaved ${ }^{(29)}$. Concentrations of total free AA and in particular some specific individual amino acids, Val (-72\%), Gln (-60\%) and Lys ( $-40 \%)$, also decreased in the autoclaved formulas. Higher concentrations of ammonia found after autoclaving suggested degradation of protein and AA.

\section{Dry heating}

Dry heat treatment of protein flours includes processing treatments such as dry roasting and micronization (a thermal treatment based on infrared heating). Despite the heat processing applied, dry roasting and micronization reduced the IVPD of cowpea, pea and kidney bean by 5.72-7.96 and 2.75$3.72 \%$, respectively, when compared with raw legumes ${ }^{(15)}$ (Table 2). IAAs and PDCAAS, however, increased after roasting and micronization for the majority of seeds studied. The reduction in protein digestibility was attributed to nonenzymatic browning (Maillard reaction) between the reducing sugars from starch hydrolysis and the proteins, as well as the thermal cross-linking that occurred during heating ${ }^{(15)}$. For sorghum proteins a decrease of $4 \%$ in protein digestibility was observed after dry heating and protein extractability was not affected ${ }^{(19)}$.

\section{Smoking and broiling}

Essential AA in rainbow trout were reported to be generally much higher in raw samples than after smoking and broiling ${ }^{(30)}$. Lys was particularly affected and in overheated fish, was drastically reduced compared to untreated fish. Compared with raw rainbow trout, broiling reduced the digestibility of protein (i.e., $\%$ decrease) by $1.63-3.9 \%$ and smoking by $4 \cdot 2-$ $4.5 \%$. PDCAAS of raw trout was reduced by $6 \%$ after smoking and by $3 \%$ after broiling. The decrease in protein quality was attributed to an increase in SH (sulphydryl) groups and S-S bonds, as well as complex chemical (cross-linking) reactions such as protein-protein interactions or protein-fat interactions when food was broiled at high temperatures. Smoking conditions (time, temperature, compounds of wood smoke) are all factors that can negatively influence protein digestibility.

Bender $^{(31)}$ showed that at the rather low temperature needed to cook meat there is little loss of available Lys and no loss of Met and Cys. No change in protein quality was found after roasting meat in an open pan at $163^{\circ} \mathrm{C}$ when the internal temperature did not rise above $80^{\circ} \mathrm{C}$; or when the meat was browned in an oven for 30 min then sterilised in a can $^{(31)}$. When meat is roasted the outer part reaches a high temperature and turns brown (Maillard reaction) which produces the desired roast flavour but since the roasted part is only a small fraction of the total piece of meat and, especially, when the internal temperature does not exceed about $80^{\circ} \mathrm{C}$, there is no measurable change in the quality of the protein as a whole $\mathrm{e}^{(31)}$

In another study ${ }^{(32)}$, intermediate moisture smoked beef was prepared by cook-soak/equilibration, where samples were either smoked for $18 \mathrm{~h}$ (heavy smoking) or for $4 \mathrm{~h}$ (light smoking) at $50^{\circ} \mathrm{C}$. Smoking caused a marked decrease in SDS-soluble protein and slightly decreased the available Lys and percent conversion of the haemoproteins to the cured nitrose forms. Smoking also caused increased darkening 
and hardness of the samples and a slight loss of some of the protein components.

Evans et $a l .{ }^{(33)}$ compared the protein quality of meats after standard cooking procedures by assessing the effects on relative nutritive value (RNV) and amino acid composition. Boiled tissue meats and processed meat showed higher RNV and levels of essential AAs than fried or microwave cooked or uncooked samples. However, in organ meats, cooking did not change total protein content or total essential amino acid contents relative to uncooked organ meats.

\section{Spray-drying}

Spray-drying is a downstream unit operation frequently used in the food industry to extend the shelf life of foods. Liquid foods are pumped through the nozzle of the spray dryer and brought into intimate contact with a counter current flow of hot air which causes flash vaporization of moisture leaving a shelf stable powdered particulate material. Spray drying is used for drying caseinates, whey protein, soya proteins and a variety of other products and the temperatures and times used can vary extensively for different food products. Concerns about the impact of spray-drying on protein quality include the occurrence of Maillard reactions, degradation of AA and possible conversion of L- to D- AA amongst others.

In one study where the nutritional protein quality of lactosehydrolysed milk was studied with $\mathrm{N}$ balance experiments on growing rats, the authors found that spray-drying under conditions usually used for ordinary milk gave a considerable reduction in protein quality, caused mainly or entirely by loss of biologically available Lys ${ }^{(34)}$.

A higher spray drying temperature was also found to significantly decrease protein quality and the contents of all AA in a spray-dried protein hydrolysate from black tilapia fish ${ }^{(35)}$. In vitro protein digestibility decreased from $92 \%\left(150^{\circ} \mathrm{C} / 76^{\circ} \mathrm{C}\right.$ inlet/outlet temperature) to $88.4 \%\left(180^{\circ} \mathrm{C} / 90^{\circ} \mathrm{C}\right.$ inlet/outlet temperature) and PDCAAS \% decreased from 82 to 34 , respectively with increasing processing temperature. Additionally, predicted protein efficiency ratios of the dried hydrolysates decreased from 2.97 to 2.53 .

\section{Extrusion}

Extrusion is a high temperature high shear process used in food texturization which has grown in popularity in recent times. It is used extensively in the processing of snacks, cereals, meat and a variety of other products. The high temperatures and shear pressures used during extrusion can denature or degrade proteins and AA and impact protein quality either positively or negatively.

Extrusion of pea seeds (Pisum sativum L. var. laguna) increased protein recovery slightly and decreased trypsin inhibitory activity (TIA) to negligible levels ${ }^{(36)}$. Val, Phe and Lys contents decreased significantly (10-22\%) when extrusion was carried out at $129^{\circ} \mathrm{C}$, whereas Trp decreased only when higher temperatures were used $\left(142^{\circ} \mathrm{C}\right)$. Changes were also observed in the concentrations of dietary dispensable AA, with Pro undergoing the greatest reductions (28-38\%), followed by Gly (10-15\%). Interestingly, biological indices for protein quality (NPU, TD, BV, NPR), remained unchanged after extrusion, but PDCAAS decreased from 66 (raw flour) to $55,61,59 \%$ for samples extruded at 129,135 and $142^{\circ} \mathrm{C}$, respectively.

Digestibility of hard-to-cook flour of cowpea was also improved by $56 \%$ after extrusion ${ }^{(37)}$. Furthermore, extrusion at $150^{\circ} \mathrm{C}$ significantly decreased antinutrients such as phytic acid $(33.2 \%)$, lectin (100\%), $\alpha$-amylase (100\%), and trypsin inhibitors $(38.2 \%)$. In vitro protein digestibility of common bean (Phaseolus vulgaris L.) was also improved by $72 \cdot 3-84 \cdot 5 \%$ after extrusion ${ }^{(38)}$.

Also, extrusion did not alter IVPD of soyabean and corn; however, it reduced the amount of trypsin inhibitors when a combination of the grains was extruded at $120^{\circ} \mathrm{C}^{(39)}$. Proximate composition of extruded products from corn (Zea mays) and lima bean (Phaseolus lunatus) flour blends showed increased protein and ash contents whereas fat levels decreased. The IVPD of the extrudates increased to $82 \%$ compared to the raw flours $(77 \%)^{(40)}$. Other reports in the literature suggest that extrusion conditions targeting aflatoxin reduction in peanut does not adversely affect protein nutritional quality.

In contrast, Silva et $a l^{(41)}$ found that extrusion of bovine rumen protein containing about $96 \%$ protein significantly reduced true protein digestibility from $97 \cdot 7 \%$ to $93 \cdot 1 \%$. The limiting amino acid also changed after extrusion but scores remained similar (i.e., 1.28 (Leu) for raw bovine rumen and $1 \cdot 25$ (Met + Cys) for the extruded sample). Un-truncated protein digestibility-corrected amino acid scores decreased from 125 to $116 \%$ after extrusion. In this particular example, for both raw and extruded proteins, PDCAAS values were, however, excellent (100\%) and animal growth profiles using raw and extruded rumen were also found to be comparable.

\section{Irradiation}

Food irradiation is a processing technique in which foods are subjected to ionising radiation to destroy insects and other pathogens of microbial origin and which affects food quality as well as safety. Several countries permit the use of food irradiation for safety reasons. Foods can be treated using low dose ( $>2 \mathrm{kGy})$, medium dose (2-10kGy) and high dose $(>10 \mathrm{kGy})$ radiation. Low dose irradiation is used to delay sprouting of vegetables and aging of fruits. Medium dose radiation helps to reduce levels of pathogenic organisms whereas high doses are used for food sterilisation. Food irradiation is not permitted for use to increase the nutritional value of foods; nevertheless some authors have evaluated its impact on protein quality. Bhat and Sridhar ${ }^{(42)}$ studied the impact of electron beam irradiation on the nutritional and anti-nutritional properties of lotus seeds. Their results showed a higher concentration of IAAs (Thr, Val, Leu, Tyr + Phe, and Ly) after irradiation. PDCAAS, however, significantly decreased after irradiation due to a decrease in IVPD which went from $43 \%$ for the untreated sample to $24 \%$, 
after application of $30 \mathrm{kGy}$ irradiation. The decrease in IVPD was dose dependent: (irradiation dose kGy: IVPD \% 0:43, $2 \cdot 5: 41,5: 40,7 \cdot 5: 40,10: 40,15: 41$ and 30:24) and was found to be statistically significant only at $30 \mathrm{kGy}$. Radiation levels ranging from $30 \mathrm{kGy}$ to $75 \mathrm{kGy}$ have been used for example for microbial disinfection of spices and seasonings, sterilisation of frozen packaged meats for astronauts, and meals for immuno compromised hospital patients.

\section{Fermentation}

Food fermentation has been used in many cultures since ancient times to preserve food and improve taste. The fermentation process involves the use of a variety of micro-organisms such as bacteria, moulds and yeasts which may be naturally present in or on the food or expressly added to induce fermentation. Fermentation provides a technological alternative for improving the nutritional value of a great variety of legumes and cereals while maintaining acceptable sensory properties ${ }^{(43)}$. The micro-organisms used in fermentation synthesise enzymes which hydrolyse food constituents and contribute to the development of products with desirable organoleptic properties. Furthermore, the hydrolysis could contribute to the decrease or elimination of anti-nutritional factors which could help in improving nutritional quality of the food.

Angulo-Bejarano et $a l .{ }^{(44)}$ reported an improved protein digestibility of chickpea flour after solid-state fermentation (SSF). In this study, chickpea seeds were soaked, seed coats removed, and cotyledons were cooked at $90^{\circ} \mathrm{C}$ for $30 \mathrm{~min}$ and inoculated with a suspension of $R$. oligosporus and fermented at $34.9^{\circ} \mathrm{C}$ for $51.3 \mathrm{~h}$ followed by drying at $52^{\circ} \mathrm{C}$ for $12 \mathrm{~h}$ and milling. Proteins from unfermented and fermented flours had IVPD of $72 \%$ and $83 \%$, respectively. True protein digestibility (in vivo) increased form $84 \%$ to $89 \%$ and PER, NPR and PDCAAS improved from 1.6 to $2 \cdot 3,2.7$ to 3 and from 73 to $92 \%$, respectively, as a consequence of the cooking/fermentation process. The improvement of PER during fermentation was attributed to better availability of AA and greater digestibility of the proteins in the substrates. Total sulphur AA (Met + Cys) was the first limiting IAA in proteins from untreated chickpea with an IAA score of 0.87 . In the fermented flour, Trp was the first limiting IAA with an IAA score of 0.93. The essential AA content of untreated chickpea was improved by the SSF process including levels of Ile, total sulphur AA (Met + Cys), total aromatic AA (Phe + Tyr), and Thr. The control sample for this study was, however, raw uncooked flour. To quantify the effect of fermentation it would have been useful if the authors had provided the protein quality results of the flour, cooked without the fermentation step.

In another similar study ${ }^{(43)}$, SSF increased the content of IAA in maize from 41 to $49 \mathrm{~g}$ IAA $100 \mathrm{~g}$ protein. His, Ile, Leu, Lys and Trp increased by $0 \cdot 8,0.5,1.5,1.5$ and $0.12 \mathrm{~g} / 100 \mathrm{~g}$ protein, respectively. Total sulphur AA (Met \& Cys) and total aromatic AA (Tyr \& Phe) increased by 0.6 and $3.5 \mathrm{~g} / 100 \mathrm{~g}$ protein, respectively. Some AA levels, notably Val, however decreased from $6 \cdot 1$ to $4 \cdot 3 \mathrm{~g} / 100 \mathrm{~g}$ protein. First and second limiting IAAs in the untreated flour were Lys $(0.72)$ and $\operatorname{Trp}(0.73)$, but this changed after fermentation to Trp (0.84) and Lys (0.98), respectively. Overall, fermentation increased protein quality indicators as follows: true protein digestibility from 76.6 to $86.8 \%$, protein efficiency ratio (PER) from 1.8 to 2.1 and PDCAAS from 55 to $83 \%$.

Nicolau et al. ${ }^{(45)}$ found the protein content in boiled rice doubled after solid state fermentation using a strain of Saccharomycopsis fibuligera, an amylase producing yeast. The increase was attributed to the yeast biomass which contributed protein rich in Lys (an amino acid limiting in rice), Met and Trp. The fermented rice was enriched in B group vitamins (B1, B2, and B6) synthesized by the yeast and phosphorus bioavailability also increased as result of fermentation. Fermentation also promoted an increase of $39.6 \%$ in the protein digestibility of sorghum proteins and an increase in protein extractability ${ }^{(19)}$.

A tempeh-type fermented product was susscesfully prepared from fresh and hardened common beans ${ }^{(46)}$ using Rhizopus oligosporus. Soluble solids, total and soluble proteins, soluble carbohydrates and $\mathrm{pH}$ of both bean samples increased after fermentation whereas fat and fibre content decreased. Trypsin inhibitor units (TIU/g d.b) decreased from $120,000-130,000$ in raw beans to $61,090-65,000$ after soaking/dehulling/cooking (SDC) to 250 - 900 after fermentation. Phytic acid levels did not change much by the SDC treatment but significantly decreased from $2 \cdot 1$ to $1 \cdot 4 \mathrm{~g} / 100 \mathrm{~g}$ d.b after fermentation. Cooking also reduced the lectin level significantly to almost undetectable levels and as a result this value did not change much after fermentation. The results suggest that the Rhyzopus oligosporus used for fermentation was capable of hydrolyzing the trypsin inhibitor and phytic acid of the substrate which may explain the improvements in protein quality in the previous studies reported above.

More recently, Fagbemi et al. ${ }^{(47)}$ also found fermentation to be the most effective processing method to reduce phytic acid and trypsin inhibitor activity in mature seeds of breadnut, cashew nut and fluted pumpkin, whereas boiling was most effective in reducing tannin content. Boiling, fermentation, germination and roasting reduced TIA of the seed flours by $20 \cdot 4,88 \cdot 7,0 \cdot 9$ and $26 \cdot 8 \%$ (breadnut); 57.1, 67.1, 34.5, and $58.7 \%$ (cashew nut); 100, 100, 94 and 100\% (pumpkin), respectively. Boiled samples had the highest IVPD (most digestible) followed by the fermented samples.

Interestingly, not all authors have observed increases in nutritional quality after fermentation. Kannan et al. ${ }^{(17)}$ found no statistically significant increase in either TPD or PDCAAS values upon fermentation of black bean products.

In the dairy sector, proteins in yogurt, acidophilus milk, and bifidus milk have been found to be more digestible than those in unfermented milk $^{(48)}$. The enhanced digestibility is attributed to protein denaturation and hydrolysis during fermentation, which results in the formation of smaller, more digestible curds. Pre-hydrolysis of milk proteins, as indicated by increased levels of free AA, especially Pro and Gly, occurs during the manufacture of yogurt ${ }^{(49)}$. Cultured yogurt 
has a significantly higher protein quality than the mix from which it is made as evidenced by in vivo digestibility, net protein ratio and computed protein efficiency ratio ${ }^{(48)}$. The activity of proteolytic enzymes and peptidases is apparently preserved throughout the shelf life of yogurt: the concentration of free amino groups increases up to twofold during the first $24 \mathrm{~h}$ and then doubles again during the next $21 \mathrm{~d}$ of storage at $7^{\circ} \mathrm{C}^{(49)}$. Some bacterial cultures have greater proteolytic activity during milk fermentation and storage than others (as indicated by elevated concentrations of peptides and free AA after milk fermentation) ${ }^{(49)}$. Both heating and fermentation reportedly contribute to the high protein quality of yogurt.

Overall, when a summary of the evidence is taken into consideration, fermentation may be a useful processing technique to reduce anti-nutritional factors in plant based proteins which could contribute to improving protein digestibility as well as protein quality. For animal protein as well, fermentation may contribute to further improvements in quality.

Protein quality evaluation methods and recommended intakes currently used in different countries

Various terminologies are used in the literature to describe nutritional requirements. Table 3 provides a description of some of the most frequently used ones. To promote adequate nutrition, countries around the world provide recommendations for intake of different nutrients including protein. As proteins play a critical role in health, methods to assess their

Table 3. Different terminologies used in the literature to describe nutritional requirements

Acronym Definition and Description ${ }^{\mathrm{a}}$

quality, efficient methods of processing to enhance their nutritive value and safe levels of intake need to be established. Some country specific protein recommended intakes and quality evaluation methods are provided in Table 4. Average and safe levels of protein intake recommended by the $\mathrm{WHO} / \mathrm{FAO} / \mathrm{UNU}^{(6)}$ are shown in Table 5 and recommendations for essential AA in Table 6.

It is important to note that the recommended dietary intake (RDI) is set at 1.96 times the standard deviations (SD) above the estimated average requirement (i.e., when requirement for the nutrient is symmetrically distributed) in order to meet the nutrient requirements of nearly all (97-98\%) healthy individuals in a particular life stage and gender group. The National Health and Medical Research Council (NHMRC) ${ }^{(50,51)}$ in Australia defines RDI as "the levels of intake of essential nutrients considered,... on the basis of available scientific knowledge, to be adequate to meet the known nutritional needs of practically all healthy people ... they incorporate generous factors to accommodate variations in absorption and metabolism. They therefore apply to group needs. RDIs exceed the actual nutrient requirements of practically all bealthy persons and are not synonymous with requirements".

Interpretation of the RDI especially in relation to evaluating protein quality and determining appropriate amounts for labeling purposes can sometimes be challenging for consumers and industry. The Codex Alimentarius and some countries (e.g., USA) therefore provide specific guidelines ${ }^{(52,53)}$. Furthermore, as processing, matrix and the presence of bioactives can
Al

AMDR

DRI

DRV

$\% \mathrm{DV}$

EAR

$\mathrm{RDA} / \mathrm{RDI}$

RDI

$\mathrm{RNI}$

SL

UL
Adequate Intake (used when EAR values are not available): Average daily nutrient intake estimated using the best approach scientifically available (e.g., observed or experimentally determined approximations or estimates of observed median nutrient intakes by a group (or groups) of healthy people) to describe an acceptable intake level or range.

Acceptable Macronutrient Distribution Ranges: Range of intakes for a particular energy source that is associated with reduced risk of chronic disease while providing adequate intakes of essential nutrients. The AMDR is expressed as a percentage of total energy intake. Recommended for calculating \%DV of macronutrients (fat, protein, carbohydrate).

Dietary Reference Intake: Includes the EAR, RDA, Al and UL. For the DRIs a requirement is defined as the lowest continuing intake level of a nutrient that, for a specific indicator of adequacy, will maintain a defined level of nutrition in an individual.

Daily Reference Value: DRVs are label reference values originally established for eight nutrients for which there were no National Academy of Sciences (NAS) Recommended Dietary Allowances (RDAs) at the time. Based on a body of scientific literature linking diet and the risk of chronic disease, the Food and Drug Administration (FDA) of the United States of America established DRVs as label reference values for total fat, saturated fat, cholesterol, total carbohydrate, dietary fiber, sodium, potassium, and protein based on a 2,000 calorie diet.

Percent Daily Value: Percentage of the Recommended Daily Allowance provided by a specified amount of food (i.e., serving and/or portion size) on a nutrition label. Intended not only to help individuals compare different products within a food type, but also to help them understand nutrition information about foods. The \%DV is based on population-weighted EARs or Als.

Estimated Average Requirement: A daily nutrient intake level expected to satisfy the needs of half of the apparently healthy individuals in that age and gender group.

Recommended Dietary Allowance/ Recommended Dietary Intake: Estimate of the minimum daily average dietary intake of a nutrient which is considered sufficient to meet the requirements of nearly all (97-98\%) healthy individuals in a particular life-stage and gender group. This value is usually 2SD above the EAR when the requirement is symetrically distributed in a population.

Reference Daily Intake: Denote(s) those nutrients whose label reference values have been derived from the NAS RDA and Estimated Safe and Adequate Daily Dietary Intakes.

Reference Nutrient Intake: Provides an estimate of the amount of nutrient that should meet the needs of most of the group $(97.5 \%)$ to which they apply (Similar to RDA/RDI).

Safe Level: Defined as the 97.5th percentile of the population distribution of requirement (average protein requirement of the individuals in the population, plus twice the SD).

Upper Level: The highest level of consumption shown to be safe based on current data. At intakes above the UL, the potential risk of adverse effects may increase.

a Source: Ref 88; 89; 6 
Table 4. Country specific recommended protein intakes and quality evaluation methods

\begin{tabular}{|c|c|c|c|c|c|c|c|c|c|}
\hline \multirow{2}{*}{ Country } & \multicolumn{7}{|c|}{ Protein Recommended Intake } & \multirow[b]{2}{*}{$\begin{array}{c}\text { Protein Quality } \\
\text { Assessment Method }\end{array}$} & \multirow[b]{2}{*}{ Reference } \\
\hline & Age & $\begin{array}{l}\text { EAR (g/kg } \\
\text { body } \\
\text { weight) }\end{array}$ & $\begin{array}{l}\text { EAR } \\
\text { (g/day) }\end{array}$ & $\begin{array}{l}\mathrm{RDA} / \mathrm{RDI} \text { or } \mathrm{Al}^{*} \\
\text { (g/kg body } \\
\text { weight) }\end{array}$ & $\begin{array}{l}\text { RDA/RDI } \\
\text { or } \mathrm{Al}^{*} \\
(\mathrm{~g} / \text { day }) \\
\end{array}$ & AMDR & $\begin{array}{l}\text { Reference } \\
\text { body weight } \\
(\mathrm{kg})\end{array}$ & & \\
\hline \multirow{12}{*}{$\begin{array}{l}\text { Australia and } \\
\text { New Zealand }\end{array}$} & $0-6$ months & & & $1.43^{*}$ & $10^{*}$ & \multirow{12}{*}{$\begin{array}{l}\text { Upper bound of AMDR is recommended } \\
\text { for those aged } 14 \text { years and above }\end{array}$} & $7^{\mathrm{a}}$ & \multirow[t]{12}{*}{ Not found } & \multirow[t]{12}{*}{ (51) } \\
\hline & 7-12 months & & & $1 \cdot 6^{*}$ & $14^{*}$ & & $9^{b}$ & & \\
\hline & $1-3 \mathrm{yr}$ & 0.92 & 12 & 1.08 & 14 & & 13 & & \\
\hline & $4-8 \mathrm{yr}$ & 0.73 & 16 & 0.91 & 20 & & 22 & & \\
\hline & $9-13$ yr (M) & 0.78 & 31 & 0.94 & 40 & & 40 & & \\
\hline & $9-13$ yr (F) & 0.61 & 24 & 0.87 & 35 & & 40 & & \\
\hline & $14-18$ yr (M) & 0.76 & 49 & 0.99 & 65 & & 64 & & \\
\hline & $14-18$ yr (F) & 0.62 & 35 & 0.77 & 45 & & 57 & & \\
\hline & $19-70$ yr (M) & 0.68 & 52 & 0.84 & 64 & & 76 & & \\
\hline & $19-70$ yr (F) & 0.60 & 37 & 0.75 & 46 & & 61 & & \\
\hline & $>70 \mathrm{yr}(\mathrm{M})$ & 0.86 & 65 & 1.07 & 81 & & 76 & & \\
\hline & $>70$ yr $(F)$ & 0.75 & 46 & 0.94 & 57 & & 61 & & \\
\hline \multirow[t]{10}{*}{ Canada } & $0-6$ months & & & $1.52^{\star}$ & $9 \cdot 1^{*}$ & \multirow{3}{*}{$\begin{array}{l}\text { AMDR for protein is set at } 5-20 \% \text { of } \\
\text { total calories for } 1-3 \mathrm{yr} ;\end{array}$} & $6^{a}$ & \multirow[t]{10}{*}{ PDCAAS / PER } & \multirow[t]{10}{*}{ (90) } \\
\hline & $7-12$ months & 1.0 & 9 & 1.2 & 11 & & 9 & & \\
\hline & $1-3 \mathrm{yr}$ & 0.87 & $10 \cdot 4$ & 1.05 & 13 & & 12 & & \\
\hline & $4-8 y r$ & 0.76 & 15 & 0.95 & 19 & \multirow{7}{*}{$\begin{array}{l}10-30 \% \text { for } 4-18 y r \\
10-35 \% \text { for }>18 y r\end{array}$} & 20 & & \\
\hline & $9-13$ yr (M) & 0.76 & 27 & 0.95 & 34 & & 36 & & \\
\hline & $9-13$ yr $(F)$ & 0.76 & 28 & 0.95 & 34 & & 37 & & \\
\hline & $14-18$ yr (M) & 0.73 & 44.5 & 0.85 & 52 & & 61 & & \\
\hline & $14-18$ yr (F) & 0.71 & 38 & 0.85 & 46 & & 57 & & \\
\hline & $>19$ yr $(\mathrm{M})$ & 0.66 & 46 & 0.8 & 56 & & 70 & & \\
\hline & $>19 \mathrm{yr}(\mathrm{F})$ & 0.66 & 38 & 0.8 & 46 & & 57 & & \\
\hline \multirow{7}{*}{$\mathrm{UK}^{\mathrm{c}}$} & $1-3$ yrs & & & & 15 & \multirow[t]{7}{*}{ Not found } & & \multirow[t]{7}{*}{ Not found } & \multirow[t]{7}{*}{ (92) } \\
\hline & $4-6 \mathrm{yrs}$ & & & & 20 & & & & \\
\hline & $7-10 \mathrm{yr}$ & & & & 28 & & & & \\
\hline & $11-14 \mathrm{yr}$ & & & & 42 & & & & \\
\hline & $15-18 \mathrm{yr}$ & & & & 55 & & & & \\
\hline & $19-50 \mathrm{yr}$ & & & & 55 & & & & \\
\hline & $>50 \mathrm{yr}$ & & & & 53 & & & & \\
\hline \multirow[t]{11}{*}{ USA } & $0-6$ months & & & & $9 \cdot 1^{*}$ & \multirow{11}{*}{$\begin{array}{l}\text { AMDR for protein is set at } 5-20 \% \text { of } \\
\text { total calories for } 1-3 \mathrm{yr} ; \\
10-30 \% \text { for } 4-18 \mathrm{yr} ; \\
10-35 \% \text { for }>18 \mathrm{yr} \text {. }\end{array}$} & & \multirow{11}{*}{$\begin{array}{l}\text { PDCAAS (PER, } \\
\text { reference casein) }\end{array}$} & \multirow[t]{11}{*}{$(52,91)$} \\
\hline & 7-12 months & & & & 13.5 & & & & \\
\hline & $1-3 \mathrm{yr}$ & & & 1.05 & 13 & & & & \\
\hline & $4-8 y r$ & & & 0.95 & 19 & & & & \\
\hline & $9-13$ yr (M) & & & 0.95 & 34 & & & & \\
\hline & $9-13$ yr $(F)$ & & & 0.95 & 34 & & & & \\
\hline & $14-18$ yr (M) & & & $0.85^{\mathrm{d}}$ & 52 & & & & \\
\hline & $>14 \operatorname{yr}(\mathrm{F})$ & & & 0.8 & 46 & & & & \\
\hline & $>19 \mathrm{yr}(\mathrm{M})$ & & & 0.8 & 56 & & & & \\
\hline & Pregnancy & & & $1 \cdot 1$ & 71 & & & & \\
\hline & Lactation & & & 1.3 & 71 & & & & \\
\hline
\end{tabular}

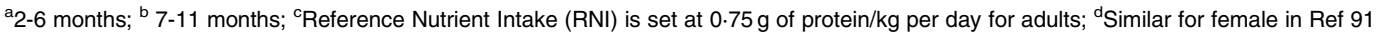


Table 5. WHO/FAO/UNU $(2007)^{6}$ recommended average and safe levels of protein intake

\begin{tabular}{|c|c|c|}
\hline $\begin{array}{l}\text { Age } \\
\text { (yr) }\end{array}$ & $\begin{array}{c}\text { Average requirement } \\
\text { (g protein } / \mathrm{kg} \text { body weight/day) }\end{array}$ & $\begin{array}{l}\text { Safe level } \\
(+1.96 S D)\end{array}$ \\
\hline 0.5 & $1 \cdot 12$ & 1.31 \\
\hline 1 & 0.95 & $1 \cdot 14$ \\
\hline 1.5 & 0.85 & 1.03 \\
\hline 2 & 0.79 & 0.97 \\
\hline 3 & 0.73 & 0.90 \\
\hline 4 & 0.69 & 0.86 \\
\hline 5 & 0.69 & 0.85 \\
\hline 6 & 0.72 & 0.89 \\
\hline 7 & 0.74 & 0.91 \\
\hline 8 & 0.75 & 0.92 \\
\hline 9 & 0.75 & 0.92 \\
\hline 10 & 0.75 & 0.91 \\
\hline \multicolumn{3}{|c|}{ Adolescent Girls } \\
\hline 11 & 0.73 & 0.90 \\
\hline 12 & 0.72 & 1.89 \\
\hline 13 & 0.71 & 1.88 \\
\hline 14 & 0.70 & 0.87 \\
\hline 15 & 0.69 & 0.85 \\
\hline 16 & 0.68 & 0.84 \\
\hline 17 & 0.67 & 0.83 \\
\hline 18 & 0.66 & 0.82 \\
\hline \multicolumn{3}{|c|}{ Adolescent Boys } \\
\hline 11 & 0.75 & 0.91 \\
\hline 12 & 0.74 & 0.90 \\
\hline 13 & 0.73 & 0.90 \\
\hline 14 & 0.72 & 0.89 \\
\hline 15 & 0.72 & 0.88 \\
\hline 16 & 0.71 & 0.87 \\
\hline 17 & 0.70 & 0.86 \\
\hline 18 & 0.69 & 0.85 \\
\hline Adults & 0.66 & 0.83 \\
\hline \multicolumn{3}{|l|}{ Pregnant $^{\star}$} \\
\hline $1^{\text {st }}$ trimester & $1 \mathrm{~g}$ protein/day & \\
\hline $2^{\text {nd }}$ trimester & $9 \mathrm{~g}$ protein/day & \\
\hline $3^{\text {rd }}$ trimester & $31 \mathrm{~g}$ protein/day & \\
\hline \multicolumn{3}{|l|}{ Lactating $^{*}$} \\
\hline$<6$ months & $19 \mathrm{~g}$ protein/day & \\
\hline$>6$ months & $12.5 \mathrm{~g}$ protein/day & \\
\hline
\end{tabular}

*Additional protein intake to that recommended for adults.

influence protein extraction, AA recovery, AAS, the first limiting amino acid and AA digestibility, it is important that these be taken into consideration in the evaluation of protein quality and in establishing labelling guidelines.

\section{Protein quality of some key food groups}

Tables 7-9 provide a list of protein quality indices for various food groups and food blends. Foods are frequently consumed in complement with other foods which raises questions as to the significance of the PDCAAS values of single protein sources. Practically all animal sources of protein have PDCAAS values equal to or above 1 (or $100 \%$ ). The excess IAA provided by these foods could be useful in complementing negative IAA balances in other foods with lower protein quality.

Although some plant sources of protein, such as soya protein isolate and soyabean have PDCAAS values close to $100 \%$, many other sources of plant protein have PDCAAS values that are much lower. Large variations in PDCAAS are evident even within food groups: for example, where pearl millet and sorghum have PDCAAS values as low as 20\%, one variety of quinoa was reported to have a PDCAAS as high as $100 \%$ (Table 7). Similarly, among tree nuts, almonds (Prunus dulcis L.) have a PDCAAS of $<25 \%$ while Baru almonds (Dipteryx alata Vog.) and tropical almonds (Terminalia catappa) have a value that is almost three times higher. The advantage of combining food proteins is evident from Table 9: by mixing sorghum and finger millet with $30 \%$ mung bean flour and 10\% nonfat milk, the PDCAAS values are increased 2-3 fold with respect to those for the grains on their own.

Concerns have been raised by some about the adequacy of plant sources of protein to provide dietary protein requirements. The American Dietetic Association ${ }^{(54)}$ has indicated that an assortment of plant foods eaten over the course of a day can provide all dietary essential AA and ensure adequate nitrogen retention and use in healthy adults, thus complementary proteins do not need to be consumed at the same meal. The ADA further clarifies that although some vegan women have protein intakes that are marginal, typical protein intakes of lacto-ovo-vegetarians and of vegans when well planned appear to meet and exceed requirements and can also provide adequately for the protein needs of athletes.

\section{Key issues still requiring consideration in protein quality} evaluation

There still remains a myriad of issues requiring consideration in relation to the evaluation of protein quality. A few of these issues are provided below.

\section{Amino acid scoring patterns}

The amino acid scoring patterns in use at the present time determine the effectiveness with which absorbed dietary nitrogen can meet the indispensable amino acid requirement at the safe level of protein intake ${ }^{(5,6)}$. The safe level of intake as indicated above is set at 1.96 times the SD above the estimated average requirement. Further discussions and considerations are required as to whether the scoring patterns should be based on amino acid requirement values divided by the mean protein requirement or the safe level of protein intake. Further reflection is also required on the AA requirements of infants vs. adults (i.e., growth vs. maintenance). Infants and children have need for positive nitrogen balance to sustain growth whereas adults need nitrogen equilibrium to maintain health. Questions have also been raised about specific requirements for each of the sulphur containing IAA. Furthermore, from a practical standpoint, food regulators need to consider that it may be beneficial for industry if PDCAAS could be calculated using only one reference pattern (i.e., 1-2 yr or 3-10 yr pattern).

\section{PDCAAS truncation}

For higher quality proteins having PDCAAS values greater than 1 or $100 \%$, the current recommendation is to truncate 
Table 6. Suggested patterns of human dietary indispensible amino acid requirements

\begin{tabular}{|c|c|c|c|c|c|c|c|}
\hline \multirow{2}{*}{$\begin{array}{l}\text { Amino Acid } \\
\text { (mg/g crude protein) }\end{array}$} & \multicolumn{4}{|c|}{ FAO/WHO/UNU 1985} & \multicolumn{3}{|c|}{ WHO/FAO/ UNU 2007} \\
\hline & Infant & $\begin{array}{l}\text { Pre-School Child } \\
\text { (2-5 yrs) }\end{array}$ & $\begin{array}{l}\text { School Child } \\
\text { (10-12 yrs) }\end{array}$ & Adult $^{\mathrm{b}}$ & Adult $^{\mathrm{C}}$ recalculated from 1985 & $\begin{array}{c}\text { Adult }^{\mathrm{c}} \\
\text { (average) }\end{array}$ & $\begin{array}{c}\text { Adult }^{\mathrm{d}} \\
\text { (Safe level) }\end{array}$ \\
\hline His $\left(I A A^{a}\right)$ & 26 & 19 & 19 & 16 & 15 & 15 & 19 \\
\hline Ile (IAA) & 46 & 28 & 28 & 13 & 15 & 30 & 38 \\
\hline Leu (IAA) & 93 & 66 & 44 & 19 & 21 & 59 & 73 \\
\hline Lys (IAA) & 66 & 58 & 44 & 16 & 18 & 45 & 56 \\
\hline Met + Cys (IAA) & 42 & 25 & 22 & 17 & 20 & 22 & 27 \\
\hline Met & & & & & & $(16)$ & 20 \\
\hline Cys & & & & & & (6) & 7 \\
\hline Phe + Tyr (IAA) & 72 & 63 & 22 & 19 & 21 & 38 & 47 \\
\hline Thr (IAA) & 43 & 34 & 28 & 9 & 11 & 23 & 29 \\
\hline $\operatorname{Trp}(\mathrm{IAA})$ & 17 & 11 & 9 & 5 & 5 & 6 & 7 \\
\hline Val (IAA) & 55 & 35 & 25 & 13 & 15 & 39 & 48 \\
\hline
\end{tabular}

IAA-Indispensible amino acid; a Conditionally indispensable (children); ${ }^{b}$ Based on a safe level of intake of $0.75 \mathrm{~g}$ protein $/ \mathrm{kg}$ per day); ${ }^{\mathrm{c} B a s e d}$ on a mean nitrogen requirement of $105 \mathrm{mg}$ nitrogen $/ \mathrm{kg}$ per day $\left(0.66 \mathrm{~g}\right.$ protein $/ \mathrm{kg}$ per day); ${ }^{\mathrm{d} B a s e d}$ on the assumption that the inter-individual coefficient of variation of the requirements for amino acids is the

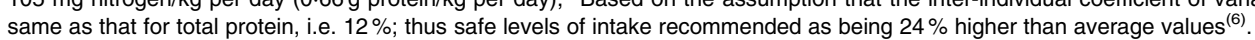

the value to the maximum value of 1 . As a mixture of proteins may be consumed in the diet over any given period of time in the course of a day, the extra IAA provided by higher quality proteins could complement proteins lacking IAA. The description of this benefit is lost with truncation. There are also questions in regards to which value to truncate, i.e., the PDCAAS or the amino acid score prior to multiplying by the digestibility factor. The FAO/WHO 1991 Expert Consultation recommended the former whereas the WHO/FAO/UNU 2007 Expert Consultation argued, that on the basis that digestibility is first limiting, the PDCAAS value should be calculated from a truncated amino acid score value. From a biological and practical perspective, AA released after digestion of a given amount of protein will be based on the total amount of AA initially present in the protein and not on a truncated amount, thus the FAO/WHO 1991 recommendation to truncate the PDCAAS score rather than the AA score seems valid. Further discussions are evidently required on this issue.

\section{Calculation of the amino acid score for a dietary protein mixture}

In calculating the amino acid score for a food protein mixture, where the digestibility of individual constituents varies, the FAO/WHO 1991 Expert Committee recommended calculating the PDCAAS using a weighted average protein digestibility and AA score calculated from the weighted amino acid content per gram of dietary protein. The WHO/FAO/UNU 2007 report recommended that the composition and amino acid score of the absorbed available AA in a mixture will reflect the relative digestibility of the individual food protein constituents, thus the amino acid score for food mixtures should be calculated from the weighted average digestible amino acid content. This is valid. However, a concern with the example provided in the WHO/FAO/UNU 2007 report is that digestibility could be construed to have been used "twice" not "once" in calculating the PDCAAS (first in calculating available protein, and then secondly to calculate the PDCAAS). A simpler recommendation would be to base the digestible amino acid value on the original amount of protein present in the diet rather than on the digestible protein which would make the second use of the digestibility function unnecessary.

\section{Use of faecal vs. ileal digestibility}

The FAO/WHO 1991 Expert Committee recommended the standardized rat faecal-balance method as the most suitable practical method for predicting protein digestibility. As pointed out by the WHO/FAO/UNU 2007 report, although faecal digestibility is probably the most appropriate measure of overall nitrogen digestibility, it is unlikely to be a true measure of amino acid digestibility. Digestibility measurements at the ileal level may provide a better measure of amino acid digestibility, however this may pose significant challenges for many researchers.

\section{Use of in vivo vs. in vitro techniques in calculating protein digestibility}

Animal studies to determine true protein digestibility can be expensive, thus, cheaper in vitro methods that accurately estimate true protein digestibility are needed. Hsu et al. ${ }^{(55)}$ and Satterlee et al. ${ }^{(56)}$ developed a multienzyme in vitro system consisting of trypsin, chymotrypsin and peptidase. The $\mathrm{pH}$ of a protein suspension immediately after $10 \mathrm{~min}$ digestion with the multienzyme solution at $37^{\circ} \mathrm{C}^{(55)}$, or after an additional $10 \mathrm{~min}$ incubation with microbial protease at $55^{\circ} \mathrm{C}^{(56)}$ was highly correlated with the in vivo apparent faecal digestibility of rats (0.90 with a standard error of estimate of 2.23 for the first study). Pedersen and Eggum ${ }^{(57)}$ developed a pH-stat assay in which initial rate of alkali consumption is used to calculate a rate of hydrolysis of peptide bonds. McDonough et al. ${ }^{(58)}$ also standardized a pH-stat method for in vitro digestibility.

Various workers have reported good correlations between some of the in vitro methods proposed and in vivo digestibility $^{(30,59-62)}$. Some legumes, however, appear to have higher in vitro values compared to the in vivo values. Carias et al. ${ }^{(63)}$ 


\section{Nesitish Journal of Nutrition}

Table 7. Protein digestibility-corrected amino acid score (PDCAAS) for cereals, meat proteins, vegetables and tree nuts ${ }^{\mathrm{a}}$

\begin{tabular}{|c|c|c|c|c|c|c|c|c|c|}
\hline Food & Food Processing & $\begin{array}{l}\text { Total protein } \\
\text { g/100 g edible } \\
\text { portion, } \\
\text { unless } \\
\text { indicated. }\end{array}$ & $\begin{array}{l}\text { Protein } \\
\text { digestibility (\%) }\end{array}$ & $\begin{array}{l}\text { LAA (as per } \\
\text { reference) }\end{array}$ & $\begin{array}{l}\text { PDCAAS (\%) } \\
\text { reported }\end{array}$ & $\begin{array}{l}\text { PDCAAS }(\%) \\
\text { re-calculated using } \\
\text { reference pattern } \\
\text { for } 1-2 \text { yr child, } \\
\text { and LAA }\end{array}$ & $\begin{array}{l}\text { PDCAAS (\%) } \\
\text { re-calculated using } \\
\text { reference pattern } \\
\text { for } 3-10 \mathrm{yr} \text { child, } \\
\text { and LAA }{ }^{\mathrm{c}}\end{array}$ & $\begin{array}{l}\text { Methods used } \\
\text { (reference pattern } \\
\text { and digestion) }\end{array}$ & Reference \\
\hline \multicolumn{10}{|c|}{ Cereals and cereal proteins } \\
\hline Barley & Air-dried at $40^{\circ} \mathrm{C}$ & 11.9 (DM) & $75 \cdot 3$ & $\begin{array}{c}\text { (data not } \\
\text { given) }\end{array}$ & (data not given) & 49, Lys & 53 , Lys & In vivo (pig). Trp nd. & $(93)^{d}$ \\
\hline $\begin{array}{l}\text { Buckwheat } \\
\text { (var. Siva } \\
\text { dolenjska) }\end{array}$ & (data not given) & $12 \cdot 3$ (DM) & 79.9 & $\begin{array}{l}\text { (data not } \\
\text { given) }\end{array}$ & (data not given) & 77, Leu, Lys & 80 , Leu & In vivo (rat). & (94) \\
\hline $\begin{array}{l}\text { Buckwheat } \\
\text { (var. Bednja 4n) }\end{array}$ & (data not given) & $12 \cdot 2(\mathrm{DM})$ & 78.8 & $\begin{array}{c}\text { (data not } \\
\text { given) }\end{array}$ & (data not given) & 75, Leu, Lys & 77, Leu & In vivo (rat). & (94) \\
\hline Maize (Corn) & Meal & 6.9 & $82 \cdot 4$ & Lys & 37 & 41, Lys & 45, Lys & $\begin{array}{l}\text { 2-5 yr child. In vivo } \\
\text { (rat). Trp nd. }\end{array}$ & $(95)^{\mathrm{e}}$ \\
\hline $\begin{array}{l}\text { Maize, Quality } \\
\text { Protein Maize, } \\
\text { V-537 }\end{array}$ & Nixtamalized extruded flour. & $10 \cdot 8$ (DM) & 80.9 & Lys & 57 & 64, Lys & 69, Ile & 2-5 yr child. In vitro. & (96) \\
\hline \multirow[t]{2}{*}{ Oats } & Ground & $13 \cdot 6$ (DM) & $85 \cdot 7$ & $\begin{array}{c}\text { (data not } \\
\text { given) }\end{array}$ & (data not given) & 71, Lys & 77 , Lys & $\begin{array}{l}\text { In vivo (rat) and } \\
\text { in vitro. In vivo used } \\
\text { when PDCAAS } \\
\text { re-calculated. }\end{array}$ & $(97)^{f}$ \\
\hline & & $(10 \cdot 0-16 \cdot 1)$ & $\begin{array}{l}(83-90) \\
93 \cdot 3(91-95) \text { in vitro } \\
\text { simulated total } \\
\text { tract; } 90 \cdot 7 \text { (88-92) } \\
\text { in vitro simulated } \\
\text { ileal }\end{array}$ & & & & & & \\
\hline Oats & $\begin{array}{l}\text { Rolled oats. Finely ground, } \\
\text { autoclaved } 15 \mathrm{~min} \text { at } \\
121^{\circ} \mathrm{C} \text {, freeze dried. }\end{array}$ & 16.8 (DM) & 90 & Lys & 66 & $\begin{array}{l}\text { (AA data not } \\
\text { given) }\end{array}$ & $\begin{array}{l}\text { (AA data not } \\
\text { given) }\end{array}$ & $\begin{array}{l}\text { NRC 1980. In vivo } \\
\text { (rat). }\end{array}$ & $(98)^{9}$ \\
\hline $\begin{array}{l}\text { Pearl Millet } \\
\text { (cv. Dempy) }\end{array}$ & Raw flour & $13 \cdot 0$ & 73.6 & Lys & 24 & 21 , Met + Cys & $\begin{array}{l}\text { 23, Met + Cys, } \\
\text { Lys }\end{array}$ & $\begin{array}{l}\text { FAO/WHO } 1973 \text {. } \\
\text { In vitro. His and Trp } \\
\text { nd. }\end{array}$ & $(99)^{\mathrm{h}}$ \\
\hline $\begin{array}{l}\text { Pearl Millet } \\
\text { (cv. Dempy) }\end{array}$ & $\begin{array}{l}\text { Cooked flour (flour mixed } \\
\text { with water and boiled } \\
20 \mathrm{~min} \text {. Cooked gruel } \\
\text { dried at } 65^{\circ} \mathrm{C} \text { and } \\
\text { reground). }\end{array}$ & $12 \cdot 9$ & 57.6 & Lys & 14 & $\begin{array}{l}\text { 15, Lys, Met }+ \\
\text { Cys }\end{array}$ & 16, Lys & $\begin{array}{l}\text { FAO/WHO } 1973 . \\
\text { In vitro. His and Trp } \\
\text { nd. }\end{array}$ & (99) \\
\hline $\begin{array}{l}\text { Quinoa } \\
\text { (var. 40057) }\end{array}$ & Raw flour & 14.1 (DM) & 91.7 & Phe + Tyr & 79 & 85, Val, Lys & 89, Val & $\begin{array}{l}\text { FAO/WHO/UNU 1985, } \\
\text { but values slightly } \\
\text { different. In vivo } \\
\text { (rat). }\end{array}$ & $(100)^{i}$ \\
\hline $\begin{array}{l}\text { Quinoa } \\
\text { (var. 40057) }\end{array}$ & $\begin{array}{l}\text { Washed flour (washed } \\
20 \text { min with tap water, } \\
\text { rinsed and dried, then } \\
\text { milled) }\end{array}$ & $14 \cdot 2(\mathrm{DM})$ & 91.6 & Phe + Tyr & 78 & 100, Lys & 109, Lys & $\begin{array}{l}\text { FAO/WHO/UNU 1985, } \\
\text { but values slightly } \\
\text { different. In vivo } \\
\text { (rat). }\end{array}$ & (100) \\
\hline $\begin{array}{l}\text { Rice (parental } \\
\text { rice) }\end{array}$ & $\begin{array}{l}\text { Hulled, raw, whole grain } \\
\text { ground }\end{array}$ & 8.2 & $92 \cdot 0$ & Lys & 53 & 58, Lys & 63, Lys & $\begin{array}{l}2-5 \text { yr child. In vivo. } \\
\text { Ileal (pig) }\end{array}$ & $(101)^{j}$ \\
\hline $\begin{array}{l}\text { Rice-genetically } \\
\text { modified } \\
\text { (expressing } \\
\text { human lactofer- } \\
\text { rin gene) }\end{array}$ & $\begin{array}{l}\text { Hulled, raw, whole grain } \\
\text { ground }\end{array}$ & 8.1 & 93.4 & $\operatorname{Trp}$ & 54 & 71, Trp, Lys & 76, Lys & $\begin{array}{l}2-5 \text { yr child. In vivo. } \\
\text { Ileal (pig) }\end{array}$ & (101) \\
\hline
\end{tabular}


NS British Journal of Nutrition

\begin{tabular}{|c|c|c|c|c|c|c|c|c|c|}
\hline Food & Food Processing & $\begin{array}{l}\text { Total protein } \\
\text { g/100 g edible } \\
\text { portion, } \\
\text { unless } \\
\text { indicated. }\end{array}$ & $\begin{array}{l}\text { Protein } \\
\text { digestibility (\%) }\end{array}$ & $\begin{array}{l}\text { LAA (as per } \\
\text { reference) }\end{array}$ & $\begin{array}{l}\text { PDCAAS (\%) } \\
\text { reported }\end{array}$ & $\begin{array}{l}\text { PDCAAS }(\%) \\
\text { re-calculated using } \\
\text { reference pattern } \\
\text { for } 1-2 \text { yr child, } \\
\text { and } L A A^{b}\end{array}$ & $\begin{array}{l}\text { PDCAAS (\%) } \\
\text { re-calculated using } \\
\text { reference pattern } \\
\text { for } 3-10 \text { yr child, } \\
\text { and } L A A^{c}\end{array}$ & $\begin{array}{l}\text { Methods used } \\
\text { (reference pattern } \\
\text { and digestion) }\end{array}$ & Reference \\
\hline $\begin{array}{l}\text { Sorghum, cv. } \\
\text { Orbit (non- } \\
\text { tannin), white }\end{array}$ & Whole grain flour, raw & 7.6 & $80 \cdot 6$ & Lys & 29 & 29 (Lys) & 32 (Lys) & $\begin{array}{l}\text { 1-2 yr child. In vitro. } \\
\text { Only Lys analyzed. }\end{array}$ & $(102)^{k}$ \\
\hline $\begin{array}{l}\text { Sorghum, cv. } \\
\text { Orbit (non- } \\
\text { tannin), }\end{array}$ & $\begin{array}{l}\text { "Ugali" unfermented thick } \\
\text { porridge, made from } \\
\text { sorghum and water }\end{array}$ & $2 \cdot 2$ & 64.6 & $\begin{array}{l}\text { (assumed } \\
\text { Lys) }\end{array}$ & 26 & 26 (Lys) & 28 (Lys) & $\begin{array}{l}\text { 1-2 yr child. In vitro. } \\
\text { Only Lys analyzed. }\end{array}$ & (102) \\
\hline $\begin{array}{l}\text { Sorghum, cv. NS } \\
\text { 5511, red }\end{array}$ & Whole grain flour, raw & 9.9 & 61.8 & Lys & 19 & 19 (Lys) & 21 (Lys) & $\begin{array}{l}\text { 1-2 yr child. In vitro. } \\
\text { Only Lys analyzed. }\end{array}$ & (102) \\
\hline $\begin{array}{l}\text { Sorghum, cv. NS } \\
5511\end{array}$ & $\begin{array}{l}\text { "Ugali" unfermented thick } \\
\text { porridge, made from } \\
\text { sorghum (cv. orbit) and } \\
\text { water }\end{array}$ & $2 \cdot 8$ & 32.6 & $\begin{array}{l}\text { (assumed } \\
\text { Lys) }\end{array}$ & 10 & 10 (Lys) & 11 (Lys) & $\begin{array}{l}\text { 1-2 yr child. In vitro. } \\
\text { Only Lys analyzed. }\end{array}$ & (102) \\
\hline Wheat & Flour & 11.6 & 89.4 & Lys & 40 & 45, Lys & 48, Lys & $\begin{array}{l}\text { 2-5 yr child. In vivo } \\
\text { (rat). Trp nd. }\end{array}$ & (95) \\
\hline Wheat & Bread, dried and ground & $12 \cdot 8$ & $89.0(86.1)$ & Lys & 37 & 41, Lys & 45, Lys & $\begin{array}{l}2-5 \text { yr child. In vivo } \\
\text { and in vitro (brack- } \\
\text { ets). His not given. }\end{array}$ & $(103)^{\prime}$ \\
\hline $\begin{array}{l}\text { Wheat } \\
\text { (var. Cranich) }\end{array}$ & & $12 \cdot 3$ (DM) & 96.0 & & & 42, Lys & 46, Lys & In vivo (rat). & (94) \\
\hline Zein (protein) & Isolated protein from maize & $77 \cdot 3$ & 63.0 & Lys & 1 & 1 , Lys & 2 , Lys & $\begin{array}{l}2-5 \text { yr child. In vivo } \\
\text { (rat). }\end{array}$ & $(8)^{\mathrm{m}}$ \\
\hline $\begin{array}{l}\text { Milk and milk proteins } \\
\text { Milk, Full cream, } \\
\text { pasteurized }\end{array}$ & Pasteurized & 3.03 & 86.4 & $\operatorname{Trp}$ & 76 & $\begin{array}{l}113 \text { (using values } \\
\text { for Trp) }\end{array}$ & $\begin{array}{l}127 \text { (using values } \\
\text { for Trp) }\end{array}$ & 2-5 yr child. In vitro. & $(27)^{\mathrm{n}}$ \\
\hline $\begin{array}{l}\text { Milk, Full cream } \\
\text { UHT }\end{array}$ & UHT & 3.0 & 87.1 & $\operatorname{Trp}$ & 82 & $\begin{array}{l}123 \text { (using value } \\
\text { for Trp) }\end{array}$ & $\begin{array}{l}138 \text { (using values } \\
\text { for Trp) }\end{array}$ & 2-5 yr child. In vitro. & (27) \\
\hline $\begin{array}{l}\text { Milk, Full cream, } \\
\text { sterilized }\end{array}$ & Sterilized & $3 \cdot 2$ & $87 \cdot 1$ & Met + Cys & 73 & $\begin{array}{l}70 \text { (using value for } \\
\text { Met + Cys) }\end{array}$ & $\begin{array}{l}76 \text { (using values } \\
\text { for Met + Cys) }\end{array}$ & $2-5 \mathrm{yr}$ child. In vitro. & (27) \\
\hline $\begin{array}{l}\text { Milk, Semi- } \\
\text { skimmed } \\
\text { pasteurized }\end{array}$ & Pasteurized & $3 \cdot 1$ & 86.5 & $\operatorname{Trp}$ & 76 & $\begin{array}{l}113 \text { (using value } \\
\text { for Trp) }\end{array}$ & $\begin{array}{l}127 \text { (using value } \\
\text { for Trp) }\end{array}$ & 2-5 yr child. In vitro. & (27) \\
\hline $\begin{array}{l}\text { Milk, Semi- } \\
\text { skimmed UHT }\end{array}$ & UHT & $3 \cdot 1$ & $87 \cdot 3$ & $\operatorname{Trp}$ & 91 & $\begin{array}{l}136 \text { (using value } \\
\text { for Trp) }\end{array}$ & $\begin{array}{l}153 \text { (using value } \\
\text { for Trp) }\end{array}$ & 2-5 yr child. In vitro. & (27) \\
\hline $\begin{array}{l}\text { Milk, Semi- } \\
\text { skimmed steri- } \\
\text { lized }\end{array}$ & Sterilized & $3 \cdot 1$ & 86.5 & Met + Cys & 34 & $\begin{array}{l}33 \text { (using value for } \\
\text { Met + Cys) }\end{array}$ & $\begin{array}{l}36 \text { (using values } \\
\text { for Trp) }\end{array}$ & 2-5 yr child. In vitro. & (27) \\
\hline $\begin{array}{l}\text { Milk, Skimmed } \\
\text { UHT }\end{array}$ & UHT & $3 \cdot 2$ & $88 \cdot 2$ & Trp & 100 & $\begin{array}{l}148 \text { (using value } \\
\text { for Trp) }\end{array}$ & $\begin{array}{l}166 \text { (using value } \\
\text { for Trp) }\end{array}$ & 2-5 yr child. In vitro. & (27) \\
\hline Milk, Skim & Powder & $29.5(33.9)$ & $94 \cdot 0$ & Trp & 100 & 115, Met + Cys & 124, Met + Cys & $\begin{array}{l}2-5 \text { yr child. Faecal } \\
\text { (rat). }\end{array}$ & (8) \\
\hline Milk, Skim heated & $\begin{array}{l}\text { Powder, autoclaved at } \\
121^{\circ} \mathrm{C} \text { for } 1 \mathrm{~h}\end{array}$ & $29.9(33.8)$ & $77 \cdot 0$ & Lys & 31 & 34, Lys & 37, Lys & $\begin{array}{l}\text { 2-5 yr child. In vivo } \\
\text { (rat). }\end{array}$ & (8) \\
\hline $\begin{array}{l}\text { Alpha-lactalbu- } \\
\min \end{array}$ & & $74.1(85.2)$ & 99.0 & Thr & $\begin{array}{l}100 \text { (166 } \\
\text { untruncated) }\end{array}$ & Lys, 200 & Lys, 217 & $\begin{array}{l}\text { 2-5 yr child. In vivo } \\
\text { (rat). }\end{array}$ & (8) \\
\hline Casein & & 81.6 & $93 \cdot 3$ & His & 93 & 99 , His & 111 , His & $\begin{array}{l}\text { 2-5 yr child. In vivo } \\
\text { (rat). Trp nd. }\end{array}$ & (96) \\
\hline Casein & & $80.2(89.9)$ & $99 \cdot 0$ & $\operatorname{Trp}$ & $\begin{array}{l}100 \text { (120 } \\
\text { untruncated) }\end{array}$ & 131, Met + Cys & 142, Met + Cys & $\begin{array}{l}\text { 2-5 yr child. In vivo } \\
\text { (rat). }\end{array}$ & (8) \\
\hline
\end{tabular}


N British Journal of Nutrition

Table 7. Continued

\begin{tabular}{|c|c|c|c|c|c|c|c|c|c|}
\hline Food & Food Processing & $\begin{array}{l}\text { Total protein } \\
\text { g/100 g edible } \\
\text { portion, } \\
\text { unless } \\
\text { indicated. }\end{array}$ & $\begin{array}{l}\text { Protein } \\
\text { digestibility (\%) }\end{array}$ & $\begin{array}{l}\text { LAA (as per } \\
\text { reference) }\end{array}$ & $\begin{array}{l}\text { PDCAAS (\%) } \\
\text { reported }\end{array}$ & $\begin{array}{l}\text { PDCAAS }(\%) \\
\text { re-calculated using } \\
\text { reference pattern } \\
\text { for } 1-2 \text { yr child, } \\
\text { and } L A A^{b}\end{array}$ & $\begin{array}{l}\text { PDCAAS }(\%) \\
\text { re-calculated using } \\
\text { reference pattern } \\
\text { for 3-10 yr child, } \\
\text { and } \text { LAA }^{c}\end{array}$ & $\begin{array}{l}\text { Methods used } \\
\text { (reference pattern } \\
\text { and digestion) }\end{array}$ & Reference \\
\hline $\begin{array}{l}\text { Whey protein } \\
\text { concentrate }\end{array}$ & Air-dried & $83 \cdot 3$ & $100 \cdot 0(97 \cdot 0)$ & $\begin{array}{c}\text { (data not } \\
\text { given) }\end{array}$ & $100(100)$ & $\begin{array}{l}\text { (AA data not } \\
\text { given. Authors } \\
\text { have truncated } \\
\text { PDCAAS) }\end{array}$ & & $\begin{array}{l}\text { 2-5 yr child. In vivo } \\
\text { (rat) }\end{array}$ & $(9)^{\circ}$ \\
\hline $\begin{array}{l}\text { Whey protein } \\
\text { hydrosylate }\end{array}$ & Air dried & 84.4 & $99.0(98.0)$ & $\begin{array}{c}\text { (data not } \\
\text { given) }\end{array}$ & $100(100)$ & $\begin{array}{l}\text { (AA data not } \\
\text { given. Authors } \\
\text { have truncated } \\
\text { PDCAAS) }\end{array}$ & & $\begin{array}{l}\text { 2-5 yr child. In vivo } \\
\text { (rat) }\end{array}$ & (9) \\
\hline Egg & Lyophilized powder & $48 \cdot 6$ & $90 \cdot 1$ & (His) & (104) & 101, Ile & 101, Ile & $\begin{array}{l}\text { 2-5 yr child. In vivo } \\
\text { (rat). }\end{array}$ & (95) \\
\hline \multicolumn{10}{|l|}{ Meat and Poultry } \\
\hline Beef & Dried beef, ground. & $81 \cdot 8$ & $92 \cdot 4$ & (Val) & (114) & 95, Val & 99 , Val & $\begin{array}{l}2-5 \text { yr child. In vivo } \\
\text { (rat). Trp nd. }\end{array}$ & (95) \\
\hline Chicken & $\begin{array}{l}\text { Flour prepared from fresh } \\
\text { chicken breast meat, } \\
\text { dried. }\end{array}$ & $77 \cdot 3$ & $95 \cdot 2$ & (Val) & (92) & $109 \mathrm{Val}$ & 115, Val & $\begin{array}{l}\text { PDCAAS calculated } \\
\text { from reference pat- } \\
\text { tern given in paper. } \\
\text { In vivo (rat). Trp nd. }\end{array}$ & $(104)^{p}$ \\
\hline \multicolumn{10}{|l|}{$\begin{array}{l}\text { Fish and fish } \\
\text { products }\end{array}$} \\
\hline Herring & Smoked & 19.5 & 98.1 & Phe + Tyr & 109 & 118, Leu & 121, Leu & 2-5 yr child. In vitro. & $(105)^{a}$ \\
\hline Herring fillets & Salted & $12 \cdot 8$ & 97.9 & $\operatorname{Trp}$ & 97 & 121 , Val & 127, Leu & 2-5 yr child. In vitro. & (105) \\
\hline Herring fillets & Marinated & $15 \cdot 4$ & 97.8 & Trp & 93 & $122, \mathrm{Val}$ & 128, Leu & 2-5 yr child. In vitro. & (105) \\
\hline Herring & Smoked & 19.5 & 98.1 & Phe + Tyr & 109 & 118, Leu & 121, Leu & 2-5 yr child. In vitro. & (105) \\
\hline Mackerel & Smoked & $19 \cdot 7$ & 98.5 & Trp & 94 & 100, Leu & 103, Leu & 2-5 yr child. In vitro. & (105) \\
\hline Mackerel & Canned in oil & $13 \cdot 7$ & 93.5 & Phe + Tyr & 139 & 148, Leu & 153, Leu & 2-5 yr child. In vitro. & (105) \\
\hline Mackerel & Fried, in vinegar & $15 \cdot 8$ & $97 \cdot 0$ & $\operatorname{Trp}$ & 96 & 123, Leu & 127, Leu & 2-5 yr child. In vitro. & (105) \\
\hline Sprats & Canned in oil & $13 \cdot 2$ & 93.0 & Met + Cys(?) & $127(?)$ & 122, Met + Cys & 133, Met + Cys & 2-5 yr child. In vitro. & (105) \\
\hline Sprats & Smoked & $22 \cdot 0$ & 97.7 & $\operatorname{Trp}$ & 76 & 105, Leu & 108, Leu & 2-5 yr child. In vitro. & (105) \\
\hline Sardine & Canned in oil & $16 \cdot 7$ & 95.0 & Phe + Tyr & 124 & 131, Leu & 136, Leu & 2-5 yr child. In vitro. & (105) \\
\hline $\begin{array}{l}\text { Tuna } \\
\text { Vegetables }\end{array}$ & Canned in oil & $15 \cdot 7$ & $93 \cdot 7$ & Phe + Tyr & 124 & 135, Leu & 139, Leu & 2-5 yr child. In vitro. & (105) \\
\hline Kale & Cooked, freeze-dried & 17.9 (DM) & $77 \cdot 3$ & Lys & 81 & 90, Lys & 98, Lys & $\begin{array}{l}\text { 2-5 yr child. In vivo } \\
\text { (rat). }\end{array}$ & $(106)^{r}$ \\
\hline $\begin{array}{l}\text { Potato (organic } \\
\text { cultivation, } \\
\text { 2002) }\end{array}$ & Cooked, freeze-dried & 10.7 (DM) & $102 \cdot 0$ & Leu & 67 & 70, Leu & 73, Leu & $\begin{array}{l}2-5 \text { yr child. In vivo } \\
\text { (rat). }\end{array}$ & (106) \\
\hline $\begin{array}{l}\text { Potato (conven- } \\
\text { tional cultiva- } \\
\text { tion, 2002) }\end{array}$ & Cooked, freeze-dried & $7 \cdot 8$ (DM) & $101 \cdot 8$ & Leu & 81 & 85, Leu & 88 & $\begin{array}{l}2-5 \text { yr child. In vivo } \\
\text { (rat). }\end{array}$ & (106) \\
\hline \multicolumn{10}{|l|}{ Tree nuts } \\
\hline $\begin{array}{l}\text { Almond (Prunus } \\
\text { dulcis L.), var. } \\
\text { Carmel }\end{array}$ & Raw, whole almond flour. & $20 \cdot 6$ & 88.6 & Met + Cys & 23 & 22, Met + Cys & 24, Met + Cys & $\begin{array}{l}\mathrm{FAO} / \mathrm{WHO} 2-5 \mathrm{yr} . \\
\text { In vivo (rat) }\end{array}$ & $(107)^{\mathrm{s}}$ \\
\hline $\begin{array}{l}\text { Almond (Prunus } \\
\text { dulcis L.), var. } \\
\text { Mission }\end{array}$ & Raw, whole almond flour. & $23 \cdot 3$ & $92 \cdot 3$ & Met + Cys & 24 & 23, Met + Cys & 25, Met + Cys & $\begin{array}{l}\text { FAO/WHO 2-5 yr. } \\
\text { In vivo (rat) }\end{array}$ & (107) \\
\hline $\begin{array}{l}\text { Almond (Prunus } \\
\text { dulcis L.), var. } \\
\text { Nonpareil }\end{array}$ & Raw, whole Almond flour. & $21 \cdot 0$ & 82.6 & Met + Cys & 22 & 21, Met + Cys & 23, Met + Cys & $\begin{array}{l}\text { FAO/WHO 2-5 yr. } \\
\text { In vivo (rat) }\end{array}$ & (107) \\
\hline
\end{tabular}




\begin{tabular}{|c|c|c|c|c|c|c|c|c|c|}
\hline Food & Food Processing & $\begin{array}{l}\text { Total protein } \\
\text { g/100 g edible } \\
\text { portion, } \\
\text { unless } \\
\text { indicated. }\end{array}$ & $\begin{array}{l}\text { Protein } \\
\text { digestibility (\%) }\end{array}$ & $\begin{array}{l}\text { LAA (as per } \\
\text { reference) }\end{array}$ & $\begin{array}{l}\text { PDCAAS (\%) } \\
\text { reported }\end{array}$ & $\begin{array}{l}\text { PDCAAS (\%) } \\
\text { re-calculated using } \\
\text { reference pattern } \\
\text { for } 1-2 \text { yr child, } \\
\text { and } L A A^{b}\end{array}$ & $\begin{array}{l}\text { PDCAAS (\%) } \\
\text { re-calculated using } \\
\text { reference pattern } \\
\text { for } 3-10 \text { yr child, } \\
\text { and } L A A^{c}\end{array}$ & $\begin{array}{l}\text { Methods used } \\
\text { (reference pattern } \\
\text { and digestion) }\end{array}$ & Reference \\
\hline $\begin{array}{l}\text { Baru almond } \\
\text { (Dipteryx alata } \\
\text { Vog.) }\end{array}$ & $\begin{array}{l}\text { Roasted in electric oven for } \\
30 \text { min at } 140^{\circ} \mathrm{C} \text { and then } \\
\text { ground. }\end{array}$ & $\begin{array}{l}25 \cdot 8 \\
(23 \cdot 8-28 \cdot 1)\end{array}$ & 79.4 & $\begin{array}{l}\text { Met + Cys; } \\
\text { Lys ( } 1 \text { tree) }\end{array}$ & $\begin{array}{l}73(66-82) \\
(66-82)\end{array}$ & $\begin{array}{l}67 \text { (61-75), Met + } \\
\text { Cys; Lys } \\
(1 \text { tree) }\end{array}$ & $\begin{array}{l}73 \text { (66-82), Met + } \\
\text { Cys; Lys } \\
\text { (1 tree) }\end{array}$ & $\begin{array}{l}\text { WHO/FAO/UNU } 2007 \\
\text { pattern, 4-18 yrs. } \\
\text { In vivo (rat). }\end{array}$ & $(108)^{t}$ \\
\hline $\begin{array}{l}\text { Tropical almond } \\
\text { (Terminalia } \\
\text { catappa) }\end{array}$ & Defatted seed flour & 55.9 & $92 \cdot 0$ & Tyr & $\begin{array}{l}31 \text { (AAS mis- } \\
\text { calculated. } \\
\text { PDCAAS } \\
\text { should have } \\
\text { been } 76 \text { ) }\end{array}$ & 60 Lys, Val & $63, \mathrm{Val}$ & $\begin{array}{l}2-5 \text { yr child. in vivo } \\
\text { (rat) }\end{array}$ & $(109)^{\mathrm{u}}$ \\
\hline
\end{tabular}

Where authors did not give PDCAAS, it was calculated using amino acid score (AAS) of limiting amino acid and digestibility values given. Abbreviations: cv. cultivar; DM: dry matter; LAA: Limiting amino acid; nd: not determined; NRC: National research council. PDCAAS: Protein digestibility corrected amino acid score. Further details on the specific method used for the in vivo digestibility measurement (i.e., true vs apparent, faecal vs ileal) can be found in the references provided.

${ }^{b}$ PDCAAS re-calculated using LAA and reference pattern for 1-2yr child ${ }^{(6)}$. Neither the AAS nor PDCAAS were truncated. A few studies had digestibility values for individual amino acids as well as for protein. In such cases, the protein digestibility value was used. Trp and His were not determined (nd) in some studies. In all the in vivo digestibility studies with the exception of Ahrens et al. 2005 (where rats were fed raw whole almond flour), the diet fed to

animals was not the individual food item but included corn starch, sucrose, oil, vitamins, minerals, cellulose etc.
${ }^{\circ}$ PDCAAS re-calculated using LAA and reference pattern for 1-2yr child ${ }^{(6)}$ as per reference, pg 181; "Thus for children aged over 2 years and adolescents, given the minor contribution that growth makes to the requirement for these age groups, the scoring pattern differs from that of adults to only a minor extent. For this reason, when judging protein quality for schoolchildren and adolescents, it is probably more practical to use just one pattern, i.e. that derived for the age group 3-10 years."

${ }^{\mathrm{d}}$ Diets were fed as grain mono-diets with mineral, vitamin supplementation and some amino acids, to meet requirements.

${ }^{\mathrm{e}}$ The authors include digestibility and PDCAAS data for unusual products such as frog meat. Trp has apparently not been determined in the AA analyses. Diets included soyabean oil, corn starch, dextrinised corn starch cellulose, sucrose, vitamins and minerals. The article is in Portuguese.

'Oat cultivars used were Adamo, Sang, Svea, Vital, Freja and Sanna. Diets contained the oat samples as the main ingredient and were kept constant in $\mathrm{N}$-concentration by adjusting with the $\mathrm{N}$-free mixture to obtain $1.5 \% \mathrm{~N}$ in DM. ${ }^{9}$ Reference pattern used to calculate PDCAAS was National Research Council (1980) Recommended Dietary Allowances. National Academy of Sciences, Washington, DC.

" The authors note the reduction in protein digestibility of pearl millet on wet cooking.

Diets contained sucrose, maize starch, cellulose, maize oil, minerals and choline chloride.

Amino acids not given per total protein, so calculated using other data in paper, from AAS and scoring pattern. Diet included soyabean oil, vitamins, minerals and dichromium trioxide.

"The tannin-free sorghum variety (both raw and cooked) had better digestibility and higher PDCAAS when compared with the tannin containing variety. For both sorghum cultivars the digestibility of the raw flour was higher than that of the cooked products: the digestibility of sorghum proteins are reported to decrease on wet cooking due to exogenous factors (grain organisational structure, polyphenols, phytic acid, starch and non-starch polysaccharides) and endogenous factors (disulphide and non-disulphide crosslinking, kafirin hydrophobicity and changes in protein secondary structure) ${ }^{(25,105)}$. Only Lys analyzed.

'Diets included corn oil, starch, vitamins and minerals.

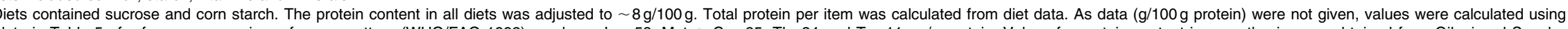
data in Table 5 of reference, assuming reference pattern (WHO/FAO 1992) used was Lys 58 , Met + Cys 25 , Thr 34 and Trp $11 \mathrm{mg} / \mathrm{g}$ protein. Values for protein content in parenthesis were obtained from Gilani and Sepehr, 2003. Although zein has a digestbilty or 63, the PDCAAS is just 1 because of is extremely low AAS (liming AA Lys, AAS. 2).

Skimmed UHT has highest PDCAAS. Sterlization leads to and Cys (49\%). Lys also decreased by $18-23 \%$. An increase in AA content and digestilly in skmed mikc. ${ }^{\circ}$ Digestibility and PDCAAS for young 5-wk-old rats given with data for 20-mo-old rats in parenthesis. Authors have truncated PDCAAS. It was not possible to recalculate the PDCAAS as individual AA data were not given. Diets contained sucrose, corn starch, lard, soyabean oil, vitamins and minerals.

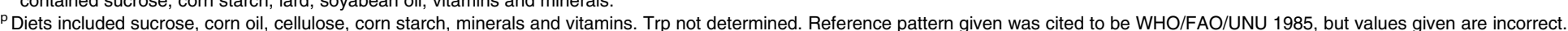

a PDCAAS for more fish items are available in reference, only a selection is shown in table above. AA data ( $\mathrm{g} / 100 \mathrm{~g}$ protein) not given for His.

'Data are for diets containing sucrose, maize starch, cellulose, soyabean oil, minerals and vitamins. The protein content in all diets was adjusted to $15 \mathrm{~g} \mathrm{~N}$ per kilogram of dry matter. The potato diets also included $5.1 \%$ casein in order to obtain the required $\mathrm{N}$ content and increase palatability (109): vegetables and fruit grown and harvested in two different years, using 3 different cultivation methods. A clear significant effect of the cultivation method was not generally seen (when both cultivation years were considered) with the exception of potato, where the conventional cultivation method gave a higher PDCAAS. Growing year influenced the protein quality more than the cultivation system.

Test diet was raw, whole almond flour. Tannins (expressed as catechin equivalents) were present at $0.12-0.18 \mathrm{~g} / 100 \mathrm{~g}$, while trypsin inhibitory activity
for all three varieties, leading to a PDCAAS of 22-24: although almond proteins are highly digestible, the protein is of poor quality due to low AAS. tDiets included cellulose, vitamins and minerals, choline bitartrate, corn starch and, for peanut diet, soyabean oil. Nuts were from 6 different sub-populations of almond trees in the south-eastern region of Goias State (Brazil).
Digestibility for individual samples is not given. Protein content varied by $6 \mathrm{~g} / 100 \mathrm{~g}$ and PDCAAS varied from $66-82 \%$ for trees from different sub-populations in the same region. The AAS (\%) varied from $83-103$, with the limiting AA being Met + Cys for five trees but Lys for the sixth tree. The PDCAAS for peanut and almond from this study are comparable, because the AAS of peanut was only $76 \%$ (c.f. average score of $92 \%$ ) for Baru almond, even though the digestibility of peanut was much higher.

u'Diet included corn starch, dextrinised corn starch, sucrose, soyabean oil, vitamins and minerals, L-Cys, choline bitartrate and butylated hydroxytoluene. 


\section{N British Journal of Nutrition}

Table 8. Protein digestibility-corrected amino acid score (PDCAAS) for some legumes ${ }^{\vee}$

\begin{tabular}{|c|c|c|c|c|c|c|c|c|c|}
\hline Food & Food Processing & $\begin{array}{l}\text { Total protein } \\
\mathrm{g} / 100 \mathrm{~g} \\
\text { edible por- } \\
\text { tion, unless } \\
\text { indicated. }\end{array}$ & $\begin{array}{l}\text { Protein } \\
\text { digestibility } \\
(\%)\end{array}$ & $\begin{array}{l}\text { LAA (as per } \\
\text { reference) }\end{array}$ & $\begin{array}{l}\text { PDCAAS } \\
\text { (\%) reported }\end{array}$ & $\begin{array}{l}\text { PDCAAS (\%) re- } \\
\text { calculated using } \\
\text { reference pattern } \\
\text { for } 1-2 \text { yr child, } \\
\text { and LAA }\end{array}$ & $\begin{array}{l}\text { PDCAAS (\%) re- } \\
\text { calculated using } \\
\text { reference pattern } \\
\text { for } 3-10 \text { yr child, } \\
\text { and LAA }\end{array}$ & $\begin{array}{l}\text { Methods used } \\
\text { (reference } \\
\text { pattern and } \\
\text { digestion) }\end{array}$ & Reference \\
\hline Beans var. Pérola & $\begin{array}{l}\text { Flour of boiled, oven-dried, } \\
\text { milled beans. }\end{array}$ & $20 \cdot 3$ & $78 \cdot 7$ & Met + Cys & 63 & 60, Met + Cys & 65, Met + Cys & $\begin{array}{l}2-5 \text { yr child. } \\
\text { In vivo (rat). } \\
\text { Trp nd. }\end{array}$ & (95) \\
\hline $\begin{array}{l}\text { Black beans, } \\
\text { common, var. } \\
\text { Talamanca }\end{array}$ & $\begin{array}{l}\text { Soaked } 12 \mathrm{~h} \text {, then cooked in } \\
\text { water for } 45 \mathrm{~min} \text {, drained } \\
\text { and lyophilized. }\end{array}$ & $28 \cdot 1$ & $80 \cdot 9$ & $\begin{array}{l}\text { Met }+ \text { Cys, } \\
\text { Trp }\end{array}$ & 38 & 61 , Met + Cys & 67, Met + Cys & $\begin{array}{l}\text { FAO/WHO/UNU } \\
1985, \text { Infant } \\
\text { requirements. } \\
\text { In vivo (rat) }\end{array}$ & $(17,110)^{y}$ \\
\hline $\begin{array}{l}\text { Black beans, } \\
\text { common, var. } \\
\text { Talamanca }\end{array}$ & $\begin{array}{l}\text { Cooked fermented beans: } \\
\text { ground bean grits soaked } \\
16 \mathrm{~h} \text {, cooked } 100^{\circ} \mathrm{C}, 22 \mathrm{~min} ; \\
\text { inoculated with Rhzopus } \\
\text { oligosporus and fermented } \\
25 \mathrm{~h}, 37^{\circ} \mathrm{C} \text {, homogenized } \\
\text { and lyophilized. }\end{array}$ & $28 \cdot 7$ & $80 \cdot 3$ & $\begin{array}{l}\text { Met + Cys, } \\
\text { Trp }\end{array}$ & 38 & 61 , Met + Cys & 66, Met + Cys & $\begin{array}{l}\mathrm{FAO} / \mathrm{WHO} / \mathrm{UNU} \\
1985, \text { Infant } \\
\text { requirements. } \\
\text { In vivo (rat) }\end{array}$ & $(17,110)$ \\
\hline $\begin{array}{l}\text { Black beans, } \\
\text { common, var. } \\
\text { Talamanca }\end{array}$ & $\begin{array}{l}\text { Cooked germinated beans: } \\
\text { germinated for } 72 \mathrm{~h} \text { at } 30^{\circ} \mathrm{C} \\
\text { at } 100 \% \text { relative humidity. } \\
\text { Germinated bean paste } \\
\text { mixed with cooked beans } \\
\text { and water }(1: 1: 1 \cdot 5) . \\
\text { Lyophilized. }\end{array}$ & $29 \cdot 2$ & $86 \cdot 8$ & $\begin{array}{l}\text { Met }+ \text { Cys, } \\
\text { Trp }\end{array}$ & 39 & 62, Met + Cys & 68, Met + Cys & $\begin{array}{l}\mathrm{FAO} / \mathrm{WHO} / \mathrm{UNU} \\
1985, \text { Infant } \\
\text { requirements. } \\
\text { In vivo (rat) }\end{array}$ & $(17,110)$ \\
\hline Black beans & Raw, ground & $18.9(21.5)$ & $71 \cdot 0$ & Met + Cys & 72 & 69, Met + Cys & 75, Met + Cys & $\begin{array}{l}2-5 \text { yr child. } \\
\text { In vivo (rat). }\end{array}$ & (8) \\
\hline Black beans & $\begin{array}{l}\text { Soaked when raw, then auto- } \\
\text { claved, dried and ground. }\end{array}$ & $19 \cdot 6(22 \cdot 7)$ & $83 \cdot 0$ & Trp & 84 & 81, Met + Cys & 88, Met + Cys & $\begin{array}{l}2-5 \text { yr child. } \\
\text { In vivo (rat). }\end{array}$ & (8) \\
\hline Chickpea & Extruded flour. & $(23, \mathrm{DM})$ & $82 \cdot 6$ & Met + Cys & 69 & $\begin{array}{l}\text { 66, Met + Cys, } \\
\text { Val }\end{array}$ & 72 (Met + Cys) & $\begin{array}{l}2-5 \text { yr child. } \\
\text { In vitro. }\end{array}$ & (97) \\
\hline Chickpea & $\begin{array}{l}\text { Defatted flour from seeds } \\
\text { soaked, decorticated, and } \\
\text { dried. }\end{array}$ & $25 \cdot 0$ & $78 \cdot 4$ & Trp & 44 & 59, Met + Cys & 64, Met + Cys & $\begin{array}{l}2-5 \text { yr child. } \\
\text { In vivo (rat). }\end{array}$ & $(14)^{z}$ \\
\hline $\begin{array}{l}\text { Cowpea, var. } \\
\text { Bechuana white }\end{array}$ & Whole grain flour, raw & $21 \cdot 2$ & 91.3 & & $\begin{array}{l}80 \text { (not } \\
\text { given) }\end{array}$ & 80 (not given) & 87 (Lys) & $\begin{array}{l}\text { 1-2 yr child. } \\
\text { In vitro. Only } \\
\text { Lys analyzed. }\end{array}$ & (102) \\
\hline Cowpea, Canadian & $\begin{array}{l}\text { Soaked, } 22 \mathrm{~h} \text {. Dried overnight } \\
\text { at } 55^{\circ} \mathrm{C} \text { and ground. }\end{array}$ & $26 \cdot 3$ & 87.5 & Met + Cys & 35 & $46 \mathrm{Met}+$ Cys & 50 Met + Cys & $\begin{array}{l}\mathrm{FAO} / \mathrm{WHO} \\
\text { 1973. In vitro. }\end{array}$ & (15) \\
\hline Cowpea, Canadian & $\begin{array}{l}\text { Microwaved } 15 \text { mins, with } \\
\text { water. Dried overnight at } \\
55^{\circ} \mathrm{C} \text { and ground. }\end{array}$ & $26 \cdot 3$ & $92 \cdot 8$ & Met + Cys & 65 & 87 Met + Cys & 95 Met + Cys & $\begin{array}{l}\text { FAO/WHO } \\
\text { 1973. In vitro. }\end{array}$ & (15) \\
\hline $\begin{array}{l}\text { Cowpea, Egyptian, } \\
\text { var. Asmerly }\end{array}$ & $\begin{array}{l}\text { Roasted for } 15 \mathrm{~min} \text { at } 180^{\circ} \mathrm{C} \text {, } \\
\text { in sand bath. Dried overnight } \\
\text { at } 55^{\circ} \mathrm{C} \text { and ground. }\end{array}$ & $26 \cdot 3$ & $76 \cdot 6$ & Met + Cys & 43 & 58 Met + Cys & 63 Met + Cys & $\begin{array}{l}\text { FAO/WHO } \\
\text { 1973. In vitro. }\end{array}$ & (15) \\
\hline $\begin{array}{l}\text { Cowpea, Egyptian, } \\
\text { var. Asmerly }\end{array}$ & $\begin{array}{l}\text { Autoclaved, with water. Dried } \\
\text { overnight at } 55^{\circ} \mathrm{C} \text { and } \\
\text { ground. }\end{array}$ & $26 \cdot 3$ & $89 \cdot 7$ & Met + Cys & 72 & 97 Met + Cys & 105 Met + Cys & $\begin{array}{l}\text { FAO/WHO } \\
\text { 1973. In vitro. }\end{array}$ & (15) \\
\hline Fava bean & Autoclaved & $27 \cdot 2$ & $82 \cdot 0(77 \cdot 0)$ & (not given) & $73(69)$ & $\begin{array}{l}\text { (AA data not } \\
\text { given.) }\end{array}$ & $\begin{array}{l}\text { (AA data not } \\
\text { given.) }\end{array}$ & $\begin{array}{l}\text { 2-5 yr child. } \\
\text { In vivo (5-wk- } \\
\text { old rats) }\end{array}$ & (9) \\
\hline
\end{tabular}


NS British Journal of Nutrition

\begin{tabular}{|c|c|c|c|c|c|c|c|c|c|}
\hline Food & Food Processing & $\begin{array}{l}\text { Total protein } \\
\mathrm{g} / 100 \mathrm{~g} \\
\text { edible por- } \\
\text { tion, unless } \\
\text { indicated. }\end{array}$ & $\begin{array}{l}\text { Protein } \\
\text { digestibility } \\
(\%)\end{array}$ & $\begin{array}{l}\text { LAA (as per } \\
\text { reference) }\end{array}$ & $\begin{array}{l}\text { PDCAAS } \\
\text { (\%) reported }\end{array}$ & $\begin{array}{l}\text { PDCAAS }(\%) \text { re- } \\
\text { calculated using } \\
\text { reference pattern } \\
\text { for } 1-2 \text { yr child, } \\
\text { and LAA }\end{array}$ & $\begin{array}{l}\text { PDCAAS }(\%) \text { re- } \\
\text { calculated using } \\
\text { reference pattern } \\
\text { for } 3-10 \text { yr child, } \\
\text { and } L A A^{\times}\end{array}$ & $\begin{array}{l}\text { Methods used } \\
\text { (reference } \\
\text { pattern and } \\
\text { digestion) }\end{array}$ & Reference \\
\hline $\begin{array}{l}\text { Fava bean (cv. } \\
\text { Diana) }\end{array}$ & $\begin{array}{l}\text { Soaked } 18 \mathrm{~h} \text {; drained; auto- } \\
\text { claved } 10 \mathrm{~min} \text { at } 121^{\circ} \mathrm{C} ; \\
\text { cooled and freeze dried. } \\
\text { Finely ground. }\end{array}$ & $\begin{array}{l}31.5 \text { ("moist- } \\
\text { ure free" } \\
\text { basis) }\end{array}$ & $86 \cdot 0$ & Trp & 55 & $\begin{array}{l}\text { (AA data not } \\
\text { given) }\end{array}$ & $\begin{array}{l}\text { (AA data not } \\
\text { given) }\end{array}$ & $\begin{array}{l}\text { NRC } 1980 . \\
\quad \text { In vivo (rat). }\end{array}$ & $(98)^{\mathrm{aa}}$ \\
\hline $\begin{array}{l}\text { Kidney bean, red, } \\
\text { Canadian }\end{array}$ & Raw & $24 \cdot 9$ & $70 \cdot 5$ & Met + Cys & 28 & 37 Met + Cys & 40 Met + Cys & $\begin{array}{l}\mathrm{FAO} / \mathrm{WHO} \\
\text { 1973. In vitro. }\end{array}$ & (15) \\
\hline $\begin{array}{l}\text { Kidney bean, red, } \\
\text { Canadian }\end{array}$ & $\begin{array}{l}\text { Cooked in microwave oven for } \\
15 \mathrm{~min} \text {, with water. }\end{array}$ & $24 \cdot 9$ & $81 \cdot 7$ & Met + Cys & 55 & 74 Met + Cys & 81 Met + Cys & $\begin{array}{l}\text { FAO/WHO } \\
\text { 1973. In vitro. }\end{array}$ & (15) \\
\hline $\begin{array}{l}\text { Kidney bean, } \\
\text { white, var. Giza } \\
3 \text { (Egyptian) }\end{array}$ & $\begin{array}{l}\text { Roasted for } 20 \mathrm{~min} \text { at } 180^{\circ} \mathrm{C} \text {, } \\
\text { in sand bath. Dried overnight } \\
\text { at } 55^{\circ} \mathrm{C} \text { and ground. }\end{array}$ & $28 \cdot 1$ & $73 \cdot 0$ & Met + Cys & 32 & 47 Met + Cys & 51 Met + Cys & $\begin{array}{l}\text { FAO/WHO } \\
\text { 1973. In vitro. }\end{array}$ & (15) \\
\hline $\begin{array}{l}\text { Kidney bean, } \\
\text { white, var. Giza } \\
3 \text { (Egyptian) }\end{array}$ & $\begin{array}{l}\text { Fermented for } 24 \mathrm{~h} \text { with dry } \\
\text { active yeast. Dried overnight } \\
\text { at } 55^{\circ} \mathrm{C} \text { and ground. }\end{array}$ & $28 \cdot 1$ & $80 \cdot 9$ & Met + Cys & 60 & 81 Met + Cys & 88 Met + Cys & $\begin{array}{l}\text { FAO/WHO } \\
\text { 1973. In vitro. }\end{array}$ & (15) \\
\hline $\begin{array}{l}\text { Lentil (Lens culi- } \\
\text { naris, cv. Medik) }\end{array}$ & $\begin{array}{l}\text { Soaked } 18 \mathrm{~h} \text {; drained; auto- } \\
\text { claved } 10 \mathrm{~min} \text { at } 121^{\circ} \mathrm{C} ; \\
\text { cooled and freeze dried. } \\
\text { Finely ground. }\end{array}$ & $\begin{array}{l}24.8 \text { ("moist- } \\
\text { ure free" } \\
\text { basis) }\end{array}$ & $85 \cdot 0$ & Trp & 52 & $\begin{array}{l}\text { (AA data not } \\
\text { given) }\end{array}$ & & $\begin{array}{l}\text { NRC } 1980 . \\
\quad \text { In vivo (rat). }\end{array}$ & (98) \\
\hline $\begin{array}{l}\text { Pea (Organic culti- } \\
\text { vation, 2002) }\end{array}$ & Cooked (and freeze-dried) & $25 \cdot 9$ (DM) & $90 \cdot 3$ & Trp & 75 & 82 Met + Cys & & $\begin{array}{l}2-5 \text { yr child. } \\
\text { in vivo (rat). }\end{array}$ & (106) \\
\hline Pea, Canadian & $\begin{array}{l}\text { Soaked } 18 \mathrm{~h} \text {. Dried overnight } \\
\text { at } 55^{\circ} \mathrm{C} \text { and ground. }\end{array}$ & $21 \cdot 6$ & $83 \cdot 7$ & Met + Cys & 33 & 44 Met + Cys & 48 Met + Cys & $\begin{array}{l}\text { FAO/WHO } \\
\text { 1973. In vitro. }\end{array}$ & (15) \\
\hline Pea, Canadian & $\begin{array}{l}\text { Cooked in microwave oven for } \\
15 \text { min, with water. Dried } \\
\text { overnight at } 55^{\circ} \mathrm{C} \text { and } \\
\text { ground. }\end{array}$ & $21 \cdot 6$ & $89 \cdot 1$ & Met + Cys & 62 & 84 Met + Cys & 91 Met + Cys & $\begin{array}{l}\text { FAO/WHO } \\
\text { 1973. In vitro. }\end{array}$ & (15) \\
\hline $\begin{array}{l}\text { Pea, var. } \\
\text { Nebraska, } \\
\text { (Egyptian) }\end{array}$ & $\begin{array}{l}\text { Roasted at } 15 \mathrm{~min} \text { at } 180^{\circ} \mathrm{C} \text {, in } \\
\text { sand bath. }\end{array}$ & $23 \cdot 1$ & $75 \cdot 0$ & Met + Cys & 33 & 44 Met + Cys & 48 Met + Cys & $\begin{array}{l}\text { FAO/WHO } \\
\text { 1973. In vitro. }\end{array}$ & (15) \\
\hline $\begin{array}{l}\text { Pea, var. } \\
\text { Nebraska, } \\
\text { (Egyptian) }\end{array}$ & $\begin{array}{l}\text { Cooked in microwave oven for } \\
15 \text { min, with water. Dried } \\
\text { overnight at } 55^{\circ} \mathrm{C} \text { and } \\
\text { ground. }\end{array}$ & $23 \cdot 1$ & 90.9 & Met + Cys & 72 & 92 lle & 92 Ile & $\begin{array}{l}\text { FAO/WHO } \\
\text { 1973. In vitro. }\end{array}$ & (15) \\
\hline Peanut & $\begin{array}{l}\text { Roasted in electric oven for } \\
30 \text { min at } 140^{\circ} \mathrm{C} \text { and then } \\
\text { ground. }\end{array}$ & $32 \cdot 6$ & $91 \cdot 8$ & Lys & 70 & 65 , Lys & 70 , Lys & $\begin{array}{l}\text { WHO/FAO/UNU } \\
2007 \text { pattern, } \\
4-18 \text { yrs. } \\
\text { In vivo (rat). }\end{array}$ & (108) \\
\hline $\begin{array}{l}\text { Peanut (Arachis } \\
\text { hypogaea L.) cv. } \\
\text { Ranferi Diaz }\end{array}$ & Defatted flour & $26 \cdot 6$ & $87 \cdot 1$ & Thr & 30 & 41, Thr & 45, Thr & $\begin{array}{l}2-5 \text { yr child. } \\
\text { In vitro. }\end{array}$ & $(111)^{\mathrm{bb}}$ \\
\hline $\begin{array}{l}\text { Peanut (Arachis } \\
\text { hypogaea L.) cv. } \\
\text { VA-81-B }\end{array}$ & Defatted flour & $24 \cdot 8$ & $84 \cdot 0$ & Thr & 50 & 66, Thr & 71, Thr & $\begin{array}{l}2-5 \text { yr child. } \\
\text { In vitro. }\end{array}$ & (111) \\
\hline $\begin{array}{l}\text { Peanut (Arachis } \\
\text { hypogaea L.) cv. } \\
\text { Florunner }\end{array}$ & Defatted flour & 24.9 & $87 \cdot 2$ & Thr & 30 & 32, Thr & $34, \mathrm{Thr}$ & $\begin{array}{l}2-5 \text { yr child. } \\
\text { In vitro. }\end{array}$ & (111) \\
\hline
\end{tabular}




\section{NS British Journal of Nutrition}

Table 8. Continued

\begin{tabular}{|c|c|c|c|c|c|c|c|c|c|}
\hline Food & Food Processing & $\begin{array}{l}\text { Total protein } \\
\mathrm{g} / 100 \mathrm{~g} \\
\text { edible por- } \\
\text { tion, unless } \\
\text { indicated. }\end{array}$ & $\begin{array}{l}\text { Protein } \\
\text { digestibility } \\
(\%)\end{array}$ & $\begin{array}{l}\text { LAA (as per } \\
\text { reference) }\end{array}$ & $\begin{array}{l}\text { PDCAAS } \\
\text { (\%) reported }\end{array}$ & $\begin{array}{l}\text { PDCAAS }(\%) \text { re- } \\
\text { calculated using } \\
\text { reference pattern } \\
\text { for } 1-2 \text { yr child, } \\
\text { and } L A A^{w}\end{array}$ & $\begin{array}{l}\text { PDCAAS }(\%) \text { re- } \\
\text { calculated using } \\
\text { reference pattern } \\
\text { for } 3-10 \text { yr child, } \\
\text { and } L A A^{\times}\end{array}$ & $\begin{array}{l}\text { Methods used } \\
\text { (reference } \\
\text { pattern and } \\
\text { digestion) }\end{array}$ & Reference \\
\hline $\begin{array}{l}\text { Soyabean } \\
\text { (conventional) }\end{array}$ & $\begin{array}{l}\text { Dry heat } 89^{\circ} \mathrm{C}, 5 \mathrm{~min} \text {. Beans } \\
\text { processed to flour. }\end{array}$ & 41.9 & $71 \cdot 8$ & Met + Cys & 54 & 52, Met + Cys & 56, Met + Cys & $\begin{array}{l}2-5 \text { yr child. } \\
\text { In vivo (rat). } \\
\text { Trp nd. }\end{array}$ & (95) \\
\hline $\begin{array}{l}\text { Soyabean (kunitz } \\
\text { trypsin inhibitor } \\
\text { and lipoxygen- } \\
\text { ase free) }\end{array}$ & $\begin{array}{l}\text { Dry heat } 89^{\circ} \mathrm{C}, 5 \mathrm{~min} \text {. Beans } \\
\text { processed to flour. }\end{array}$ & $40 \cdot 0$ & $74 \cdot 3$ & Met + Cys & 64 & 61, Met + Cys & 66, Met + Cys & $\begin{array}{l}2-5 \text { yr child. } \\
\text { In vivo (rat). } \\
\text { Trp nd. }\end{array}$ & (95) \\
\hline Soyabean & Meal, raw & $36.8(41.9)$ & $80 \cdot 0$ & Trp & 80 & 88, Met + Cys & 96, Met + Cys & $\begin{array}{l}2-5 \text { yr child. } \\
\text { In vivo (rat). }\end{array}$ & (8) \\
\hline Soyabean & Meal, autoclaved & $37.5(41.9)$ & 83.0 & Lys & 83 & 89, Met + Cys & 97, Met + Cys & $\begin{array}{l}2-5 \text { yr child. } \\
\text { In vivo (rat). }\end{array}$ & (8) \\
\hline Soyabean & Protein isolate & $75.6(81.9)$ & $96 \cdot 0$ & $\begin{array}{l}\text { Lys, Met }+ \\
\text { Cys }\end{array}$ & $\begin{array}{l}100(101 \\
\text { untrunca- } \\
\text { ted) }\end{array}$ & 97, Met + Cys & 105, Met + Cys & $\begin{array}{l}2-5 \text { yr child. } \\
\text { In vivo (rat). }\end{array}$ & (8) \\
\hline Soyabean & $\begin{array}{l}\text { Textured soyabean protein. } \\
\text { Ground to obtain meal. }\end{array}$ & $53 \cdot 3$ & $86 \cdot 4$ & Met + Cys & 65 & 62, Met + Cys & 67, Met + Cys & $\begin{array}{l}\text { 2-5 yr child. } \\
\text { In vivo (rat). } \\
\text { Trp nd. }\end{array}$ & (95) \\
\hline
\end{tabular}

v Where authors did not give PDCAAS, it was calculated using AAS of limiting amino acid and digestibility values given. Abbreviations: cv. cultivar; DM: dry matter; LAA: Limiting amino acid; nd: not determined; NRC: National research council. PDCAAS: Protein digestibility corrected amino acid score. Further details on the specific method used for the in vivo digestibility measurement (i.e., true vs apparent, faecal vs ileal) can be found in the

references provided.
"PDCAAS re-calculated using LAA and reference pattern for 1-2yr child. Neither the AAS nor PDCAAS were truncated. A few studies had digestibility values for individual amino acids as well as for protein. In such cases, the protein digestibility value was used. Trp and His were not determined in some studies. In all the in vivo digestibility studies with the exception of Ahrens et al. ${ }^{(110)}$ (where rats were fed raw, whole, almond flour), the diet fed to animals were not the individual food item but included corn starch, sucrose, oil, vitamins, minerals, cellulose etc.

PDCAAS re-calculated using LAA and reference pattern for 1-2yr child

Diets included cellulose, Com oll, con starch, Choline bitartate, vilamins and minerals.

Diets included sucrose, fat, vitamins and minerals, fibre, choline bitartrate and corn starch.

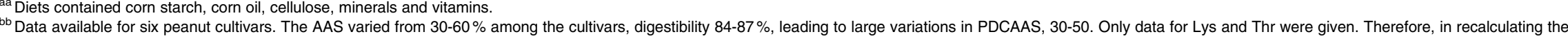
PDCAAS, it was not possible to check if the limiting AA (and PDCAAS) had changed. 
Table 9. Protein digestibility-corrected amino acid score (PDCAAS) of some composite products ${ }^{\mathrm{a}}$

\begin{tabular}{|c|c|c|c|c|c|c|c|c|c|}
\hline Food & Food Processing & $\begin{array}{l}\text { Total } \\
\text { protein } \\
\mathrm{g} / 100 \mathrm{~g} \\
\text { edible } \\
\text { portion, } \\
\text { unless } \\
\text { indicated. }\end{array}$ & $\begin{array}{l}\text { Protein } \\
\text { digestibility } \\
(\%)\end{array}$ & $\begin{array}{l}\text { LAA (as per } \\
\text { reference) }\end{array}$ & $\begin{array}{l}\text { PDCAAS } \\
(\%) \\
\text { reported }^{\mathrm{b}}\end{array}$ & $\begin{array}{l}\text { PDCAAS (\%) } \\
\text { re-calculated } \\
\text { using reference } \\
\text { pattern for } 1-2 \\
\text { yr child, and } \\
\text { LAA }^{c}\end{array}$ & $\begin{array}{l}\text { PDCAAS (\%) } \\
\text { re-calculated } \\
\text { using reference } \\
\text { pattern for 3-10 } \\
\text { yr child, and } \\
\text { LAA }^{d}\end{array}$ & $\begin{array}{l}\text { Methods used } \\
\text { (reference pattern } \\
\text { and digestion) }\end{array}$ & Reference \\
\hline Herring in tomato sauce & canned & $12 \cdot 0$ & $90 \cdot 6$ & Phe + Tyr & 105 & 110, Leu & 114, Leu & $\begin{array}{l}2-5 \text { yr child. In vitro. } \\
\text { His AA data not } \\
\text { given per } 100 \mathrm{~g} \\
\text { protein. }\end{array}$ & (105) \\
\hline Mackerel in tomato sauce & canned & $12 \cdot 7$ & $92 \cdot 2$ & Phe + Tyr & 95 & 100, Leu & 103, Leu & $\begin{array}{l}2-5 \text { yr child. In vitro. } \\
\text { His AA data not } \\
\text { given per } 100 \mathrm{~g} \\
\text { protein. }\end{array}$ & (105) \\
\hline Sprats in tomato sauce & canned & $11 \cdot 5$ & $91 \cdot 2$ & Met + Cys & 97 & 94, Met + Cys & $\begin{array}{l}\text { 101, Met + } \\
\text { Cys }\end{array}$ & $\begin{array}{l}2-5 \text { yr child. In vitro. } \\
\text { His AA data not } \\
\text { given per } 100 \mathrm{~g} \\
\text { protein. }\end{array}$ & (105) \\
\hline $\begin{array}{l}\text { Sorghum (cv. orbit) }+ \\
\text { cowpea }(70: 30 \mathrm{w} / \mathrm{w}) \text {, raw }\end{array}$ & Flour, raw & $\begin{array}{l}11.9(13.2 \\
\mathrm{DM})\end{array}$ & $85 \cdot 8$ & $\begin{array}{l}\text { (assumed } \\
\text { Lys) }\end{array}$ & 57 & 57 & 62 (Lys) & $\begin{array}{l}\text { 1-2 yr child. In vitro. } \\
\text { Only Lys ana- } \\
\text { lyzed. }\end{array}$ & $(102)^{e}$ \\
\hline $\begin{array}{l}\text { Sorghum (cv. NS 5511) + } \\
\text { cowpea }(70: 30 \mathrm{w} / \mathrm{w}) \text {, raw }\end{array}$ & Flour, raw & $\begin{array}{l}13.4(14.9 \\
\mathrm{DM})\end{array}$ & $76 \cdot 0$ & $\begin{array}{l}\text { (assumed } \\
\text { Lys) }\end{array}$ & 50 & 50 & 54 (Lys) & $\begin{array}{l}\text { 1-2 yr child. In vitro. } \\
\text { Only Lys ana- } \\
\text { lyzed. }\end{array}$ & $(102)$ \\
\hline $\begin{array}{l}\text { “Ugali” unfermented thick } \\
\text { porridge (African), made } \\
\text { from sorghum (cv. orbit) } \\
\text { + chickpea flour and } \\
\text { water }\end{array}$ & cooked & $\begin{array}{l}3 \cdot 3(13 \cdot 2 \\
\text { DM) }\end{array}$ & $72 \cdot 2$ & $\begin{array}{l}\text { (data not } \\
\text { given) }\end{array}$ & 48 & 48 & 52 (Lys) & $\begin{array}{l}\text { 1-2 yr child. In vitro. } \\
\text { Only Lys ana- } \\
\text { lyzed. }\end{array}$ & (102) \\
\hline $\begin{array}{l}\text { “Ugali” unfermented thick } \\
\text { porridge (African), made } \\
\text { from sorghum (cv. NS } \\
5511)+ \text { chickpea flour } \\
\text { and water }\end{array}$ & cooked & $\begin{array}{l}3 \cdot 7(14 \cdot 8 \\
\mathrm{DM})\end{array}$ & $56 \cdot 7$ & $\begin{array}{l}\text { (data not } \\
\text { given) }\end{array}$ & 37 & 37 & 40 (Lys) & $\begin{array}{l}\text { 1-2 yr child. In vitro. } \\
\text { Only Lys ana- } \\
\text { lyzed. }\end{array}$ & (102) \\
\hline $\begin{array}{l}\text { “Uji” fermented thin por- } \\
\text { ridge (African), made from } \\
\text { sorghum (cv. orbit) }+ \\
\text { chickpea flour and water }\end{array}$ & Cooked & $\begin{array}{l}1.6(13 \cdot 3 \\
\mathrm{DM})\end{array}$ & $77 \cdot 0$ & $\begin{array}{l}\text { (data not } \\
\text { given) }\end{array}$ & 44 & 44 & 48 (Lys) & $\begin{array}{l}\text { 1-2 yr child. In vitro. } \\
\text { Only Lys ana- } \\
\text { lyzed. }\end{array}$ & $(102)$ \\
\hline $\begin{array}{l}\text { “Uji” fermented thin por- } \\
\text { ridge (African), made from } \\
\text { sorghum (cv. NS 5511) + } \\
\text { chickpea flour and water }\end{array}$ & Cooked & $\begin{array}{l}1 \cdot 8(15 \cdot 1 \\
\mathrm{DM})\end{array}$ & $61 \cdot 0$ & $\begin{array}{l}\text { (Assumed } \\
\text { Lys) }\end{array}$ & 35 & 35 & 38 (Lys) & $\begin{array}{l}\text { 1-2 yr child. In vitro. } \\
\text { Only Lys ana- } \\
\text { lyzed. }\end{array}$ & (102) \\
\hline $\begin{array}{l}\text { “Injera” fermented flat bread } \\
\text { (African), made from sor- } \\
\text { ghum (cv. orbit) + chick- } \\
\text { pea flour, dried baker's } \\
\text { yeast and sugar. }\end{array}$ & $\begin{array}{l}\text { Cooked, then freeze dried. } \\
\text { Protein content in yeast } \\
\text { was } 38 \mathrm{~g} / 100 \mathrm{~g} \text { and Lys } \\
8 \mathrm{~g} / 100 \mathrm{~g} \text { protein. }\end{array}$ & $\begin{array}{l}5 \cdot 8(14 \cdot 2 \\
\text { DM) }\end{array}$ & $79 \cdot 8$ & $\begin{array}{l}\text { (Assumed } \\
\text { Lys }\end{array}$ & 60 & $\begin{array}{l}\text { 60, assumed } \\
\text { Lys }\end{array}$ & 65 (Lys) & $\begin{array}{l}\text { 1-2 yr child. In vitro. } \\
\text { Only Lys ana- } \\
\text { lyzed. }\end{array}$ & (102) \\
\hline $\begin{array}{l}\text { "Injera" fermented flat bread } \\
\text { (African), made from sor- } \\
\text { ghum (cv. NS 5511) + } \\
\text { chickpea flour, dried }\end{array}$ & $\begin{array}{l}\text { Cooked, then freeze dried. } \\
\text { Protein content in yeast } \\
\text { was } 38 \mathrm{~g} / 100 \mathrm{~g} \text { and Lys } \\
8 \mathrm{~g} / 100 \mathrm{~g} \text { protein. }\end{array}$ & $\begin{array}{l}6 \cdot 4(15 \cdot 6 \\
\mathrm{DM})\end{array}$ & $62 \cdot 5$ & $\begin{array}{l}\text { (Assumed } \\
\text { Lys }\end{array}$ & 41 & $\begin{array}{l}\text { 41, assumed } \\
\text { Lys }\end{array}$ & 44 (Lys) & $\begin{array}{l}\text { 1-2 yr child. In vitro. } \\
\text { Only Lys ana- } \\
\text { lyzed. }\end{array}$ & (102) \\
\hline
\end{tabular}


Table 9. Continued

\begin{tabular}{|c|c|c|c|c|c|c|c|c|c|}
\hline Food & Food Processing & $\begin{array}{l}\text { Total } \\
\text { protein } \\
\mathrm{g} / 100 \mathrm{~g} \\
\text { edible } \\
\text { portion, } \\
\text { unless } \\
\text { indicated. }\end{array}$ & $\begin{array}{l}\text { Protein } \\
\text { digestibility } \\
(\%)\end{array}$ & $\begin{array}{l}\text { LAA (as per } \\
\text { reference) }\end{array}$ & $\begin{array}{l}\text { PDCAAS } \\
(\%) \\
\text { reported }^{\mathrm{b}}\end{array}$ & $\begin{array}{l}\text { PDCAAS (\%) } \\
\text { re-calculated } \\
\text { using reference } \\
\text { pattern for } 1-2 \\
\text { yr child, and } \\
\text { LAA }^{c}\end{array}$ & $\begin{array}{l}\text { PDCAAS (\%) } \\
\text { re-calculated } \\
\text { using reference } \\
\text { pattern for 3-10 } \\
\text { yr child, and } \\
\text { LAA }^{d}\end{array}$ & $\begin{array}{l}\text { Methods used } \\
\text { (reference pattern } \\
\text { and digestion) }\end{array}$ & Reference \\
\hline $\begin{array}{l}\text { Mixed diet of pea ( } 43 \%) \text {, } \\
\text { potato }(30 \%) \text {, rapeseed oil } \\
(13 \%), \text { carrot }(5 \%) \text { apple } \\
(1 \%), \text { kale }(1 \%) \text { and } \\
\text { DL-Met, vitamins and } \\
\text { minerals. }\end{array}$ & $\begin{array}{l}\text { Potatoes, peas and kale } \\
\text { cooked. }\end{array}$ & $16 \cdot 1$ (DM) & $(72-74)$ & $\begin{array}{l}\text { Trp (lowest } \\
\text { PDCAAS) }\end{array}$ & $(63-64)$ & $\begin{array}{l}\text { (Amino acid } \\
\text { composition } \\
\text { of mixture } \\
\text { not given) }\end{array}$ & & $\begin{array}{l}2-5 \text { yr child. In vivo } \\
\text { (rat). }\end{array}$ & $(106)^{f}$ \\
\hline $\begin{array}{l}\text { Chickpea }(79 \%) \text { and maize } \\
(21 \%)\end{array}$ & $\begin{array}{l}\text { Extruded chickpea flour, } \\
\text { var. Blanco Sinaloa 92; } \\
\text { nixtamlized extruded } \\
\text { maize flour, quality pro- } \\
\text { tein maize } V-537 \text {. Mix- } \\
\text { ture containing sucrose } \\
\text { and water was heated } \\
90^{\circ} \mathrm{C} \text { for } 8 \text { min. }\end{array}$ & $20 \cdot 1$ (DM) & 84.5 & $\begin{array}{l}\text { Trp (lowest } \\
\text { PDCAAS) }\end{array}$ & 78 & 76, Val & 80, Val & 2-5 yr child. In vitro. & (96) \\
\hline $\begin{array}{l}\text { Cooking banana fruit and } \\
\text { bambara (groundnut) } \\
\text { seeds }(70: 30)\end{array}$ & $\begin{array}{l}\text { Banana, oven dried }\left(60^{\circ} \mathrm{C} \text {, }\right. \\
24 \mathrm{~h}) \text { flour. Groundnut } \\
\text { seeds roasted in hot } \\
\text { sand at } 180^{\circ} \mathrm{C} \text {, flour. }\end{array}$ & $\begin{array}{l}\text { (not } \\
\quad \text { given) }\end{array}$ & $45 \cdot 0$ & (Val) & (9.3) & 9, Val & $10, \mathrm{Val}$ & $\begin{array}{l}\text { PDCAAS calculated } \\
\text { using 1-2 yr pat- } \\
\text { tern and AA data } \\
\text { given by authors. } \\
\text { In vivo (rat). Trp } \\
\text { nd. }\end{array}$ & (112) \\
\hline $\begin{array}{l}\text { Cooking banana fruit and } \\
\text { bambara (groundnut) } \\
\text { seeds }(60: 40)\end{array}$ & $\begin{array}{l}\text { Banana, oven dried }\left(60^{\circ} \mathrm{C} \text {, }\right. \\
24 \mathrm{~h}) \text { flour. Groundnut } \\
\text { seeds roasted in hot } \\
\text { sand at } 180^{\circ} \mathrm{C} \text {, flour. }\end{array}$ & $\begin{array}{l}\text { (not } \\
\quad \text { given) }\end{array}$ & $58 \cdot 1$ & (Val) & (16) & 16, Val & 17, Val & $\begin{array}{l}\text { In vivo (rat). Trp nd. } \\
\text { PDCAAS calcu- } \\
\text { lated by using AA } \\
\text { data given by } \\
\text { authors and } 1-2 \mathrm{yr} \\
\text { pattern. }\end{array}$ & (112) \\
\hline $\begin{array}{l}\text { Table bread fortified with } \\
8 \% \text { defatted soyabean } \\
\text { meal }\end{array}$ & $\begin{array}{l}\text { Bread dried at } 50^{\circ} \mathrm{C} \text { for } \\
24 \mathrm{~h} \text {, then ground }\end{array}$ & $15 \cdot 8$ & $87.4(84.9)$ & Lys & 47 & 53 , Lys & 57 , Lys & $\begin{array}{l}\text { 2-5 yr child. In vivo } \\
\text { and in vitro } \\
\text { (brackets). His not } \\
\text { given. }\end{array}$ & $(103)^{g}$ \\
\hline $\begin{array}{l}\text { Table bread fortified with } \\
12 \% \text { defatted soyabean } \\
\text { meal }\end{array}$ & $\begin{array}{l}\text { Bread dried at } 50^{\circ} \mathrm{C} \text { for } \\
24 \mathrm{~h} \text {, then ground }\end{array}$ & $17 \cdot 3$ & $86.4(84.5)$ & Lys & 53 & 59, Lys & 64, Lys & $\begin{array}{l}\text { 2-5 yr child. In vivo } \\
\text { and in vitro } \\
\text { (brackets). His not } \\
\text { given. }\end{array}$ & (103) \\
\hline $\begin{array}{l}\text { Table bread fortified with } \\
8 \% \text { defatted soyabean } \\
\text { meal and } 4 \% \text { defatted } \\
\text { sesame meal }\end{array}$ & $\begin{array}{l}\text { Bread dried at } 50^{\circ} \mathrm{C} \text { for } \\
24 \mathrm{~h} \text {, then ground }\end{array}$ & $17 \cdot 6$ & $85.8(83.2)$ & Lys & 46 & 51 , Lys & 56 , Lys & $\begin{array}{l}\text { 2-5 yr child. In vivo } \\
\text { and in vitro } \\
\text { (brackets). His not } \\
\text { given. }\end{array}$ & (103) \\
\hline $\begin{array}{l}\text { Bean and rice, } 53 \% \text { bean } \\
\text { protein, } 47 \% \text { rice protein }\end{array}$ & $\begin{array}{l}\text { Cooked bean and cooked } \\
\text { rice. Lyophilized. }\end{array}$ & $20 \cdot 8$ & $84 \cdot 3$ & Ile and Trp & 47 & $73,11 \mathrm{e}$ & 73,11 e & $\begin{array}{l}\text { FAO/WHO/UNU } \\
1985, \text { Infant } \\
\text { requirements. } \\
\text { In vivo (rat). }\end{array}$ & $(17,110)^{\mathrm{h}}$ \\
\hline
\end{tabular}


Table 9. Continued

\begin{tabular}{|c|c|c|c|c|c|c|c|c|c|}
\hline Food & Food Processing & $\begin{array}{l}\text { Total } \\
\text { protein } \\
\mathrm{g} / 100 \mathrm{~g} \\
\text { edible } \\
\text { portion, } \\
\text { unless } \\
\text { indicated. }\end{array}$ & $\begin{array}{l}\text { Protein } \\
\text { digestibility } \\
(\%)\end{array}$ & $\begin{array}{l}\text { LAA (as per } \\
\text { reference) }\end{array}$ & $\begin{array}{l}\text { PDCAAS } \\
(\%) \\
\text { reported }^{\mathrm{b}}\end{array}$ & $\begin{array}{l}\text { PDCAAS (\%) } \\
\text { re-calculated } \\
\text { using reference } \\
\text { pattern for 1-2 } \\
\text { yr child, and } \\
\text { LAA }^{c}\end{array}$ & $\begin{array}{l}\text { PDCAAS (\%) } \\
\text { re-calculated } \\
\text { using reference } \\
\text { pattern for 3-10 } \\
\text { yr child, and } \\
\text { LAA }^{d}\end{array}$ & $\begin{array}{l}\text { Methods used } \\
\text { (reference pattern } \\
\text { and digestion) }\end{array}$ & Reference \\
\hline $\begin{array}{l}\text { Bean and rice, } 53 \% \text { bean } \\
\text { protein, } 47 \% \text { rice protein }\end{array}$ & $\begin{array}{l}\text { Cooked, fermented bean } \\
\text { and cooked rice. } \\
\text { Lyophilized. }\end{array}$ & $19 \cdot 8$ & $84 \cdot 6$ & Ile and Trp & 47 & $73,11 \mathrm{e}$ & $73,11 \mathrm{e}$ & $\begin{array}{l}\text { FAO/WHO/UNU } \\
1985, \text { Infant } \\
\text { requirements. } \\
\text { In vivo (rat) }\end{array}$ & $(17,110)$ \\
\hline $\begin{array}{l}\text { Bean and rice, } 53 \% \text { bean } \\
\text { protein, } 47 \% \text { rice protein }\end{array}$ & $\begin{array}{l}\text { Cooked, germinated bean } \\
\text { and cooked rice. Lyophi- } \\
\text { lized. }\end{array}$ & $19 \cdot 6$ & $91 \cdot 0$ & Ile and Trp & 51 & $81, \mathrm{lle}$ & 81,11 e & $\begin{array}{l}\text { FAO/WHO/UNU } \\
1985, \text { Infant } \\
\text { requirements. } \\
\text { In vivo (rat) }\end{array}$ & $(17,110)$ \\
\hline $\begin{array}{l}\text { Pearl millet (NW } 305 \text {, blue } \\
\text { seeds), mung bean (Vigna } \\
\text { radiata L.) and nonfat dry } \\
\text { milk }(60: 30: 10)\end{array}$ & $\begin{array}{l}\text { Flour of decorticated mung } \\
\text { bean splits toasted at } \\
90^{\circ} \mathrm{C}, 1 \mathrm{~h} \text {. Mung bean } \\
\text { flour, milled millet and } \\
\text { milk extruded. }\end{array}$ & $19 \cdot 0$ & $82 \cdot 8(85 \cdot 6)$ & Lys & 68 & 74 , Lys & 80 , Lys & $\begin{array}{l}\text { 2-5 yr child. In vivo } \\
\text { and in vitro } \\
\text { (brackets). } \\
\text { PDCAAS recalcu- } \\
\text { lated using in vivo } \\
\text { digestibility. Trp } \\
\text { not given. }\end{array}$ & (113) \\
\hline $\begin{array}{l}\text { Finger millet (Indaf, brick } \\
\text { red seeds), mung bean } \\
\text { (Vigna radiata L.) flour } \\
\text { and nonfat dry milk } \\
(60: 30: 10)\end{array}$ & $\begin{array}{l}\text { Flour of decorticated mung } \\
\text { bean splits toasted at } \\
90^{\circ} \mathrm{C}, 1 \mathrm{~h} \text {. Mung bean } \\
\text { flour, milled millet and } \\
\text { milk extruded }\end{array}$ & $13 \cdot 1$ & $79 \cdot 6(72 \cdot 1)$ & Lys & 69 & 69, Met + Cys & 75, Met + Cys & $\begin{array}{l}\text { 2-5 yr child. In vivo } \\
\text { and in vitro } \\
\text { (brackets). } \\
\text { PDCAAS recalcu- } \\
\text { lated using in vivo } \\
\text { digestibility. Trp } \\
\text { not given. }\end{array}$ & (113) \\
\hline $\begin{array}{l}\text { Sorghum (SPV 475, white } \\
\text { seeds), mung bean (Vigna } \\
\text { radiata L.) flour and nonfat } \\
\text { dry milk (60:30:10) }\end{array}$ & $\begin{array}{l}\text { Flour of decorticated mung } \\
\text { bean splits toasted at } \\
90^{\circ} \mathrm{C}, 1 \mathrm{~h} \text {. Mung bean } \\
\text { flour, milled millet and } \\
\text { milk extruded }\end{array}$ & $17 \cdot 0$ & $72 \cdot 9$ & Lys & 57 & 61 , Met + Cys & 66, Met + Cys & $\begin{array}{l}2-5 \text { yr child. In vitro. } \\
\text { Trp not given. }\end{array}$ & (113) \\
\hline
\end{tabular}

${ }^{a}$ In all reports, digestibility studies were carried out on actual mixture. With the possible exception of Jorgensen et al. 2008, all studies obtained the AAS from amino acid analysis done on actual mixture rather than calculating from mixture ratio of individual ingredients. Abbreviations: cv. cultivar; DM: dry matter; LAA: Limiting amino acid; nd: not determined; NRC: National research council. PDCAAS: Protein digestibility corrected amino acid score. Further details on the specific method used for the in vivo digestibility measurement (i.e., true vs apparent, faecal vs ileal) can be found in the references provided.

Where authors did not give PDCAAS, it was calculated using AAS of limiting amino acid and digestibility values given.

${ }^{\circ}$ PDCAAS re-calculated using LAA and reference pattern for 1-2yr child ${ }^{6}$. Neither the AAS nor PDCAAS were truncated. A few studies had digestibility values for individual amino acids as well as for protein. In such cases, the protein digestibility value was used. Trp and His were not determined in some studies. In all the in vivo digestibility studies the diet fed to animals were not the individual food item but included corn starch, sucrose, oil, vitamins, minerals, cellulose etc.

PDCAAS re-calculated using LAA and reference pattern for 1-2yr child ${ }^{6}$

alues for total protein content were provided by authors, personal communication. Addition of protein-rich cowpea was shown to improve both the digestibility and the PDCAAS of sorghum foods (between 2- and 3-fold higher), The aubed to the increase in Lys content and improved protein digestibility.

'The authors measured the digestibility in adult rats of a mixed diet and compared the PDCAAS thus obtained with the predicted PDCAAS from the parameters determined using young rats on single ingredients, according to FAO/WHO/UNU 1992. It is not stated if the amino acid analysis was carried out again for the mixture (mixed diet), or was calculated from the composition previously experimentally determined for the individual ingredients, as per FAO/WHO/UNU 1992. The predicted digestibility of the mixed diets was at least $5 \%$ higher than the determined digestibility. The authors concluded that the use of young rats may result in an overestimation of the protein digestibility and quality for adult animals.

Breads also contained corn oil, starch, vitamins and minerals. Unlike the PDCAAS values shown above, authors found that weight gain, in vivo PER and in vitro PER in "table bread fortified with $8 \%$ defatted soyabean meal and $4 \%$ defatted sesame meal" were only slightly lower than in "table bread fortified with $12 \%$ defatted soyabean meal", which showed the highest values for all these factors.

Diets included cellulose, corn oil, corn starch, vitamins, minerals and choline bitartrate ${ }^{(110)}$ 
used three in vitro methods ( $\mathrm{pH}$ drop, $\mathrm{pH}$ stat and pepsin digestibility) and two in vivo methods (true and apparent faecal digestibility in rats) to compare the protein digestibility of casein, soya protein isolate, fish meal, black beans, corn meal and wheat flour. All methods were in agreement for highly digestible proteins but less so for proteins with digestibilities below $85 \%$. They recommended that for non-conventional proteins or for known proteins subjected to processing, protein digestibility should be measured in vivo. Further studies are needed to ascertain the conditions under which in vitro digestibility methods can estimate apparent and/or true protein digestibility. Furthermore, the FAO/WHO 1981 recommended that amino acid scores be adjusted for "true" protein digestibility, thus the relevance of using "apparent" protein digestibility (or equivalents) should be considered. Similarly, as some studies have shown that apparent digestibility varies with the level of protein intake, some consideration should be given as to how in vitro digestibility methods estimating apparent digestibility are affected by protein concentration. In addition, some emerging research suggests that the rate of protein digestion may also be of importance in protein quality ${ }^{(7)}$

\section{Protein vs. amino acid digestibility}

Digestibility and bioavailability of AA influence protein quality. There are concerns that protein digestibility measurements may not provide accurate estimation of the digestibility of specific IAA. Thus, research is needed to determine to what extent protein digestibility as a whole (in vivo or in vitro) reflects the digestibility of specific IAA and how this may be affected by processing, matrix effects and other biotic and abiotic factors. Further research is also needed on the impact of processing on the bioavailability of specific essential AA.

\section{Impact of processing and anti-nutritional components on protein quality}

Several workers have reported that the presence of antinutritional components in some protein sources can influence their digestibility. Gilani and Sepehr ${ }^{(9)}$ concluded from protein digestibility studies using young and old rats that the use of young rats may overestimate protein quality for the elderly for proteins containing antinutritional factors. The magnitude of the effect varied by protein type as well by processing treatment when the same protein source was subjected to different treatments, which suggests both protein and processing effects. Interestingly, research is also emerging on potential health benefits of some of these "bioactive" compounds which raises questions about whether their consumption to some extent may be beneficial.

Formation of tannin-protein complexes, as an example, have shown antioxidant properties acting as potent radical cation scavengers which could make them radical sinks in the gastrointestinal tract ${ }^{(64)}$. Tannins also have antimicrobial properties. Various mechanisms for the tannin antimicrobial activity have been suggested, including inhibition of extracellular microbial enzymes, deprivation of substrates required for microbial growth, or direct action on microbial metabolism through the inhibition of oxidative phosphorylation ${ }^{(26)}$

In vivo and in vitro experiments have demonstrated marked anticancer (preventive as well as therapeutic) effects of inositol hexaphosphate $\left(\mathrm{IP}_{6} \text {, phytic acid }\right)^{(65)}$. $\mathrm{IP}_{6}$ reduced cell proliferation and increased differentiation of malignant cells resulting sometimes in reversion to the normal phenotype. Phytic acid may also be beneficial by reducing the bioavailability of toxic heavy metals such as cadmium and lead, and reducing excessive oxidation activity of iron and copper through chelation ${ }^{(66)}$. Kunitz trypsin inhibitors and BowmanBirk inhibitors isolated from legumes have been shown to function as therapeutic agents against digestive system cancer and in ulceratitis prevention, and may contain antiinflammatory activity and anti-viral activity ${ }^{(67)}$.

As it is still unknown at what concentrations these intakes may be beneficial and the specific mechanisms at play, further research specifically regarding how the presence of these socalled antinutritional compounds are affected by processing and the impact of both factors on protein quality will be useful.

\section{Conclusion}

Significant progress has been made in the last half century in defining protein quality and establishing appropriate levels of intake to support growth and maintain health. As results from new research emerge, recommendations may need to be updated or revised to maintain relevance. Changes in lifestyle, energy expenditure and new challenges in populations with high disease burdens require constant surveillance. To keep guidelines and legislations relevant, new scientific data will be required to support policy and inform expert recommendations at the global level. Some studies, for example, suggest that calorie intake and frequency of protein consumption influences nitrogen retention and should be considered in protein quality evaluation. Several studies have also shown that over and above that of basic nutrition, additional health benefits may be provided by specific amino acids and bioactive peptides ${ }^{(7,68-81)}$. On the other hand, disease risks associated with over consumption of protein and potential differences in effects of different proteins in stimulating disease is poorly understood and requires further research ${ }^{(82)}$. Additionally, an important issue that will require consideration is whether the recommended protein intakes for public health purposes are based on assumptions of a particular protein quality of the diet. This is of interest as dietary protein quality can vary depending on social, economic and other geographic factors. Further discussions are also needed on the practical interpretation and use of the term 'safe' or 'upper level' to describe recommended protein intakes. For example, the $2007 \mathrm{WHO} / \mathrm{FAO} / \mathrm{UNU}$ Report $^{(6)}$ notes that "the term 'safe intake' also includes the concept that there is no risk to individuals from excess protein intakes up to levels considerably above the safe intake". As we move towards the year 2050 and beyond, particular challenges around the paradox of under-nutrition/malnutrition and over-nutrition, especially as 
related to protein intake and consequent disease burdens, will also need to be given greater attention.

\section{Acknowledgements}

a) Contributions made by each author to the manuscript: $\mathrm{BB}$, JIB - Conceived and designed outline of manuscript. RW, JIBWrote the manuscript. BB, RW, JIB - Revised manuscript.

b) Conflict of interest: The authors state that there are no conflicts of interest.

c) Funding: This work received no specific grant from any funding agency in the public, commercial or not-for-profit sectors.

\section{References}

1. FAO (1957) Protein requirements. Report of the FAO Committee. FAO Nutritional Studies, No. 16, Rome.

2. FAO (1965) Protein requirements. Report of a Joint FAO/ WHO Expert Group, Geneva, World Health Organization, WHO Technical Report Series, No. 301, Geneva.

3. FAO/WHO (1973) Energy and protein requirements. Report of a Joint FAO/WHO ad hoc Expert Committee. WHO Technical Report Series, No. 522, Geneva.

4. FAO/WHO/UNU Expert Consultation (1985) Energy and Protein Requirements. WHO Technical Report Series 724, Geneva.

5. FAO/WHO Expert Consultation (1991) Protein Quality Evaluation Report of the Joint FAO/WHO Expert Consultation held in Bethseda, Md., USA, in 1989. FAO Food and Nutrition Paper 51, Rome.

6. WHO/FAO/UNU (2007) Protein and amino acid requirements in human nutrition: report of a joint WHO/FAO/ UNU expert consultation. WHO Technical Report Series 935. Geneva. FAO/WHO/UNU, 276.

7. Millward DJ, Layman DK, Tomé D, et al. (2008) Protein quality assessment: Impact of expanding understanding of protein and amino acid needs for optimal health. $\mathrm{Am}$ J Clin Nutr 87, 1576S-1581S.

8. Sarwar G (1997) The protein digestibility-corrected amino acid score method overestimates quality of proteins containing antinutritional factors and of poorly digestible proteins supplemented with limiting amino acids in rats. J Nutr 127, 758-764.

9. Gilani GS \& Sepehr E (2003) Protein digestibility and quality in products containing antinutritional factors are adversely affected by old age in rats. $J$ Nutr $\mathbf{1 3 3}, 220-225$.

10. Stein HH, Sève B, Fuller MF, et al. (2007) Invited review: Amino acid bioavailability and digestibility in pig feed ingredients: Terminology and application. J Anim Sci $\mathbf{8 5}$, $172-180$.

11. Levesque CL, Moehn S, Pencharz PB, et al. (2010) Review of advances in metabolic bioavailability of amino acids. Livestock Sci 133, 4-9.

12. Uppal V \& Bains K (2012) Effect of germination periods and hydrothermal treatments on in vitro protein and starch digestibility of germinated legumes. J Food Sci Technol 49, 184-191.

13. Nalle CL, Ravindran G \& Ravindran V (2010) Influence of dehulling on the apparent metabolisable energy and ileal amino acid digestibility of grain legumes for broilers. $J$ Sci Food Agric 90, 1227-1231.

14. Tavano OL, Da Silva Jr SI, Démonte A, et al. (2008) Nutritional responses of rats to diets based on chickpea
(Cicer arietinum L.) seed meal or its protein fractions. J Agric Food Chem 56, 11006-11010.

15. Khattab RY, Arntfield SD \& Nyachoti CM (2009) Nutritional quality of legume seeds as affected by some physical treatments. Part 1: Protein quality evaluation. LWT - Food Science Technol 42, 1107-1112.

16. Abu EG, Ahmed Y \& Abdalla Abdelsamad A (2007) Effect of domestic processing methods on chemical composition, in vitro digestibility of protein and starch and functional properties of Bambara groundnut (Voandzeia subterranea). Seed Res J Agric Biol Sci 3, 1, 24-34.

17. Kannan S, Nielsen SS \& Mason AC (2001a) Protein Digestibility-Corrected Amino Acid Scores for bean and bean rice infant weaning food products. J Agric Food Chem 49 , 5070-5074.

18. Jirapa P, Normah H, Zamaliah MM, et al. (2001) Nutritional quality of germinated cowpea flour (Vigna unguiculata) and its application in home prepared powdered weaning foods. Plant Foods Human Nutr 56, 203-216.

19. Correia I, Nunes A, Barros AS, et al. (2010) Comparison of the effects induced by different processing methods on sorghum proteins. J Cereal Sci 51, 146-151.

20. Ramakrishna V, Jhansi Rani P \& Ramakrishna Rao P (2008) Nutritional quality of storage proteins during germination of indian bean (Dolichos lablab. var. lignosus) seeds. Int J Food Sci Technol 43, 944-949.

21. Ghavidel RA \& Prakash J (2007) The impact of germination and dehulling on nutrients, antinutrients, in vitro iron and calcium bioavailability and in vitro starch and protein digestibility of some legume seeds. LWT - Food Sci Technol 40, 1292-1299.

22. Osman MA (2007) Effect of different processing methods, on nutrient composition, antinutrional factors, and in vitro protein digestibility of dolichos lablab bean [Lablab purpuresus (L) sweet]. Pakistan J Nutr 6, 299-303.

23. Shimelis EA \& Rakshit SK (2007) Effect of processing on antinutrients and in vitro protein digestibility of kidney bean (Phaseolus vulgaris L.) varieties grown in East Africa. Food Chem 103, 161-172.

24. Saleh AA \& El-Adawy TA (2006) Nutritional composition of chickpea (Cicer arietinum L.) as affected by microwave cooking and other traditional cooking methods. I Food Comp Anal 19, 806-812.

25. Duodu KG, Taylor JRN, Belton PS, et al. (2003) Factors affecting sorghum protein digestibility. J Cereal Sci 38, $117-131$.

26. Scalbert A (1991) Antimicrobial properties of tannins. Phytochem 30, 3875-3883.

27. Boschi V, Traisci MV, Siervo M, et al. (2002) Protein quality assessment in milk after technological treatment. Progress Nutr 4, 3, 221-225.

28. Andersson I \& Öste R (1994) Nutritional quality of pasteurized milk. Vitamin B12, folate and ascorbic acid content during storage. Int Dairy J 4, 161-172.

29. Yeung CY, Lee HC, Lin SP, et al. (2006) Negative effect of heat sterilization on the free amino acid concentrations in infant formula. Euro J Clin Nutr 60, 136-141.

30. El SN \& Kavas A (1996) Determination of protein quality of rainbow trout (Salmo irideus) by in vitro protein digestibility corrected amino acid score (PDCAAS). Food Chem $\mathbf{5 5}$, 221-223.

31. Bender A (1992) Meat and meat products in human nutrition in developing countries. FAO Food and Nutrition Paper 53. 
32. Okonkwo TM, Obanu ZA \& Ledward DA (1992) Characteristics of some intermediate moisture smoked meats. Meat Sci 31, 135-145.

33. Evans E, Carruthers SC \& Witty R (1979) Effects of cooking methods on the protein quality of meats as determined using a Tetrahymena pyriformis W GRoWTlj ASSAY. J Food Sci 44, 1678.

34. Burvall A, Asp N-G, Dahlqvist A, et al. (1977) Nutritional value of lactose-hydrolysed milk: protein quality after some industrial processes. J Dairy Res 44, 549-553.

35. Abdul-Hamid A, Bakar J \& Bee GH (2002) Nutritional quality of spray dried protein hydrolysate from Black Tilapia (Oreochromis mossambicus). Food Chem 78, 69-74.

36. Frias J, Giacomino S, Peñas E, et al. (2011) Assessment of the nutritional quality of raw and extruded pisum sativum L. var. laguna seeds. LWT - Food Sci Technol 44, 1303-1308.

37. Batista KA, Prudêncio SH \& Fernandes KF (2010a) Changes in the biochemical and functional properties of the extruded hard-to-cook cowpea (Vigna unguiculata L. walp). Int J Food Sci Technol 45, 794-799.

38. Batista KA, Prudêncio SH \& Fernandes KF (2010b) Changes in the functional properties and antinutritional factors of extruded hard-to-cook common beans (Phaseolus vulgaris L.). J Food Sci 75, C286-C290.

39. Bertipaglia LMA, DeMelo GMP, Sugohara A, et al. (2008) Chemical changes in soyabean and corn processed by extrusion. Revista Brasileira de Zootecnia 37, 11, 2003-2010.

40. Pérez-Navarrete C, Betancur-Ancona D, Casotto M, et al. (2007) Effect of extrusion on protein and starch bioavailability in corn and lima bean flour blends. [Efecto de la extrusión sobre la biodisponibilidad de proteína y almidón en mezclas de harinas de maíz y frijol lima]. Archivos Latinoamericanos De Nutricion 57, 278-286.

41. Silva ACCE, Cruz RJD \& Arêas JAG (2010) Influence of thermoplastic extrusion on the nutritive value of bovine rumen protein. Meat Sci 84, 409-412.

42. Bhat R \& Sridhar KR (2008) Nutritional quality evaluation of electron beam-irradiated lotus (Nelumbo nucifera) seeds. Food Chem 107, 174-184.

43. Cuevas-Rodríguez EO, Verdugo-Montoya NM, AnguloBejarano PI, et al. (2006) Nutritional properties of tempeh flour from quality protein maize (Zea mays L.). LWT Food Sci Technol 39, 1072-1079.

44. Angulo-Bejarano PI, Verdugo-Montoya NM, Cuevas-Rodríguez EO, et al. (2008) Tempeh flour from chickpea (Cicer arietinum L.) nutritional and physicochemical properties. Food Chem 106, 106-112.

45. Nicolau AL, Georgescu LA, Segal R (2009) The impact of bioprocessing on rice nutritional quality. Paper presented at the 5th International Technical Symposium on Food Processing, Monitoring Technology in Bioprocesses and Food Quality Management 236-243.

46. Paredes-López O \& Harry GI (1989) Changes in Selected Chemical and Antinutritional Components during Tempeh Preparation Using Fresh and Hardened Common Beans. J Food Sci 54, 968-970.

47. Fagbemi TN, Oshodi AA \& Ipinmoroti KO (2005) Processing effects on some antinutritional factors and in vitro multienzyme protein digestibility (IVPD) of three tropical seeds: breadnut (Artocarpus altilis), cashewnut (Anacardium occidentale) and fluted pumpkin (Telfairia occidentalis). Pakistan J Nutr 4, 4, 250-256.
48. Lee H, Friend BA \& Shahani KM (1988) Factors affecting the protein quality of yogurt and acidophilus milk. J Dairy Sci 71, 3203-3213.

49. Adolfsson O, Meydani SN \& Russell RM (2004) Yogurt and gut function. Am J Clin Nutr 80, 245-256.

50. National Health and Medical Research Council (NHMRC) (1991) Recommended Dietary Intakes for use in Australia. Canberra.

51. Nutrient reference values for Australia and New Zealand Including Recommended Dietary Intakes (2006) Australian Government, Ministry of Health, Department of Health and Ageing, National Health and Medical Research Council, Australia; available at www.nhmrc.gov.au/_files_nhmrc/ file/publications/synopses/n35.pdf (accessed April 2011).

52. Electronic Code of Federal Regulations (2011) Title 21 Food and Drugs (FDA, 21 CFR 101.9(c)(7)(iii)); available at http://ecfr.gpoaccess.gov/cgi/t/text/text-idx?sid=fa782cad56 $43525 \mathrm{c} 2 \mathrm{be} 020 \mathrm{a} 4 \mathrm{~d} 560 \mathrm{c} 005 \& \mathrm{c}=$ ecfr\&tpl=/ecfrbrowse/Title21/ 21tab_02.tpl (accessed April 2011).

53. Codex Alimentarius (1985) Guidelines on Nutrition labelling CAC/GL 2-1985 Adopted 1985. Revision 1993. Amendment 2003, 2006, 2009, 2010.

54. American Dietetic Association (ADA) (2003) Position of the American Dietetic Association and Dietitians of Canada: Vegetarian diets. J Amer Diet Assoc 103, 748-765.

55. Hsu HW, Vavak DL, Satterlee LD, et al. (1977) A multienzyme technique for estimating protein digestibility. J Food Sci 42, 1269-1273.

56. Satterlee DL, Marshall HF \& Tennyson JM (1979) Measuring protein quality. J Am Oil Chem Soc 56, 103-109.

57. Pedersen B \& Eggum BO (1983) Prediction of protein digestibility by an in vitro enzymatic $\mathrm{pH}$-stat procedure. Zt Tierphysiol Tierernahr Furtermitt 4, 265-277.

58. McDonough FE, Sarwar G, Steinke FH, et al. (1990) In vitro assay for protein digestibility: interlaboratory study. $J$ Ass Analyt Chem 13, 622-625.

59. Bodwell EC, Satterlee DL \& Hackler RL (1980) Protein digestibility of the same protein preparations by human and rat assays and by in vitro enzymic digestion methods. Am J Clin Nutr 33, 677-686.

60. Rich N, Satterlee DL \& Smith LJ (1980) A comparison of in vivo apparent protein digestibility in man and rat to in vitro protein digestibility as determined using human and rat pancreatins and commercially available proteases. Nutr Rep Int 21, 285-300.

61. Eggum BO, Kreft I \& Javornik B (1980) Chemical composition and protein quality of buckwheat (Fagopyrum esculentum Moench). Qualitas Plantarum Plant Foods Human Nutr 30, 3-4, 175-179.

62. Marletta L, Carbonara M \& Carnovale E (1992) In vitro protein and sulphur amino acid availability as a measure of bean protein quality. J Sci Food Agric 59, 497-504.

63. Carias D, Cioccia AM \& Hevia P (1995) Agreement between animal and vegetable protein digestibility measured in vivo and in vitro and its effect on the chemical score. Arch Latinoam Nutr 45, 111-116.

64. Riedl KM \& Hagerman AE (2001) Tannin-protein complex as radical scavengers and radical sinks. J Agric Food Chem 49, 4917-4923.

65. Shamsuddin AM (2002) Anti-cancer function of phytic acid. Int J Food Sci Technol 37, 769-782.

66. Campos-Vega R, Loarca-Pina G \& Oomah BD (2010) Minor components of pulses and their potential impact on human health. Food Res Int 43, 461-482.

67. Ribeiro JKC, Cunha DDS, Fook JMSLL, et al. (2010) New properties of the soybean trypsin inhibitor: Inhibition of 
human neutrophil elastase and its effect on acute pulmonary injury. European J Pharmacol 644, 238-244.

68. Kong B \& Xiong YL (2006) Antioxidant activity of zein hydrolysates in a liposome system and the possible mode of action. I Agric Food Chem 54, 6059-6068.

69. Li HM, Ping G, Xin H, et al. (2007) Preparation of corn (Zea mays) peptides and their protective effect against alcohol-induced acute hepatic injury in NH mice. Biotechnol Appl Biochem 47, 169-174.

70. Guo H, Sun J, He H, et al. (2009) Antihepatotoxic effect of corn peptides against Bacillus Calmette-Guerin/lipopolysaccharide-induced liver injury in mice. Food Chem Toxicol 47, 2431-2435.

71. De Leo F, Panarese S, Gallerani R, et al. (2009) Angiotensin converting enzyme (ACE) inhibitory peptides: Production and implementation of functional food. Curr Pharm Des 15, 31, 3622-3643.

72. Regazzo D, Da Dalt L, Lombardi A, et al. (2010) Fermented milks from enterococcus faecalis TH563 and lactobacillus delbrueckii subsp. bulgaricus LA2 manifest different degrees of ACE-inhibitory and immunomodulatory activities. Dairy Sci Technol 90, 469-476.

73. Atanasova J \& Ivanova I (2010) Antibacterial peptides from goat and sheep milk proteins. Biotechnol Biotechnolog Equip 24, 1799-1803.

74. Boye JI, Roufik S, Pesta N, et al. (2010a) Angiotensin I-converting enzyme inhibitory properties and SDS-PAGE of red lentil protein hydrolysates. LWT-Food Sci Technol 43, 987-991.

75. Barbana C \& Boye JI (2010) Angiotensin I-converting enzyme inhibitory activity of enzymatic chickpea and pea protein hydrolysates. Food Res Int 43, 1642-1649.

76. Barbana C \& Boye JI (2011) Angiotensin I-converting enzyme inhibitory properties of enzymatic lentil protein hydrolysates. Food Chem 127, 94-101.

77. Barbana C, Boucher AC \& Boye JI (2011) In vitro binding of bile salts by lentil flours, lentil protein concentrates and lentil protein hydrolysates. Food Res Int 44, 1, 174-180.

78. Pupovac J \& Anderson GH (2002) Dietary peptides induce satiety via cholecystokinin-A and peripheral opioid receptors in rats. J Nutr 132, 2775-2780.

79. Erdmann K, Cheung BWY \& Schröder H (2008) The possible roles of food-derived bioactive peptides in reducing the risk of cardiovascular disease. J Nutr Biochem 19 , 643-654.

80. Hochstenbach-Waelen A, Nieuwenhuizen A \& WesterterpPlantenga M (2008) Effects of alpha-lactalbumin, gelatin with or without added tryptophan-protein breakfasts on hunger, 'satiety' hormones, and protein kinetics. Appetite 51, 373.

81. Katsanos CS, Kobayashi H, Sheffield-Moore M, et al. (2006) A high proportion of leucine is required for optimal stimulation of the rate of muscle protein synthesis by essential amino acids in the elderly. Am J Physiol Endocrinol Metab 291, E381-E386.

82. Millward DJ (2004) Protein and amino acid requirements of athletes. J Sports Sci 22, 143-145.

83. Alsmeyer RH, Cunningham AE \& Happich ML (1974) Equations predict PER from amino acid analysis. Food Technol 28, 34-40.

84. Buamah TF \& Singsen EP (1975) Studies on the protein efficiency ratio method for the evaluation of poultry feed supplements. Modifications associated with choice of dietary protein level for assay. $J$ Nutr 105, 688-700.

85. Addo K, Lykins S \& Cotton C (1996) Indigenous fermentation and soy fortification: effects on protein quality and carbohydrate digestibility of a traditional Ghanaian corn meal. Food Chem 51, 377-380.

86. Schaafsma G (2000) The Protein Digestibility-Corrected Amino Acid Score. J Nutr 130, 1865S-1867S.

87. Srikantia SG (1981) The use of biological value of a protein in evaluating its quality for human requirements; available at www.fao.org/docrep/meeting/004/m2835e/m2835e00. HTM (accessed April 2011).

88. FDA (1993) Food labeling: Reference Daily Intakes and Daily Reference Values. Part IV, final rule. Fed Regist 58, 2206-2228.

89. IOM (2003) Dietary Reference Intakes: Guiding principles for nutrition labeling and fortification. Committee on Use of Dietary Reference Intakes in Nutrition Labeling. Washington, USA: Institute of Medicine of the National Academies, The National Academic Press.

90. Health Canada (2011) Dietary Reference Intakes; available at www.hc-sc.gc.ca/fn-an/nutrition/reference/table/ref_ macronutr_tbl-eng.php

91. USDA Dietary Guidelines Advisory Committee (DGAC) (2010) Report of the Dietary Guidelines Advisory Committee on the Dietary Guidelines for Americans, 2010, to the Secretary of Agriculture and the Secretary of Health and Human Services U.S. Department of Agriculture, Agricultural Research Service, Washington, DC. May 2010. http:// www.cnpp.usda.gov/Publications/DietaryGuidelines/2010/ DGAC/Report/2010DGACReport-camera-ready-Jan11-11.pdf (accessed April 2011).

92. Report on Health and Social Subjects 41 (1991) Dietary Reference Values (DRVs) for Food Energy and Nutrients for the UK Report of the Panel on DRVs of the Committee on Medical Aspects of Food Policy (COMA) The Stationary Office. London. www.food.gov.uk/multimedia/pdfs/nutguideuk.pdf and cited reference (accessed April 2011).

93. Hackl W, Pieper B, Pieper R, et al. (2010) Effects of ensiling cereal grains (barley, wheat, triticale and rye) on total and pre-caecal digestibility of proximate nutrients and amino acids in pigs. J Anim Phys Anim Nutr 94, 729-735.

94. Eggum BO, Hansen I \& Larsen T (1989) Protein quality and digestibility energy of selected foods determined in balance trials with rats. Plant Foods Human Nutr 39, 13-21.

95. Pires CV, Almeida Oliveira MGD, Cesar Rosa J, et al. (2006) Nutritional quality and chemical score of amino acids from different protein sources. Ciencia e Tecnologia de Alimentos 26, 179-187.

96. Milán-Carrillo J, Valdéz-Alarcón C, Gutiérrez-Dorado R, et al. (2007) Nutritional properties of quality protein maize and chickpea extruded based weaning food. Plant Foods Human Nutr 62, 31-37.

97. Pettersson A, Lindberg JE, Thomke S, et al. (1996) Nutrient digestibility and protein quality of oats differing in chemical composition evaluated in rats and by an in vitro technique. Animal Feed Sci Technol 62, 203-213.

98. Sarwar G \& Peace RW (1986) Comparisons between true digestibility of total nitrogen and limiting amino acids in vegetable proteins fed to rats. J Nutr 116, 1172-1184.

99. Ali MAM, El Tinay AH, Mallasy LO, et al. (2010) Supplementation of pearl millet flour with soybean protein: Effect of cooking on in vitro protein digestibility and essential Amino Acids composition. Int J Food Sci Technol 45, 740-744

100. Ruales J \& Nair BM (1992) Nutritional quality of the protein in quinoa (Chenopodium quinoa, Willd) seeds. Plant Foods Human Nutr 42, 1-11. 
101. Hu Y, Li M, Piao J, et al. (2010) Nutritional evaluation of genetically modified rice expressing human lactoferrin gene. J Cereal Sci 52, 350-355.

102. Anyango JO, de Kock HL \& Taylor JRN (2011) Impact of cowpea addition on the Protein Digestibility Corrected Amino Acid Score and other protein quality parameters of traditional African foods made from non-tannin and tannin sorghum. Food Chem 124, 775-780.

103. Serna Saldivar SO, Abril-Dominguez JR, López-Ahumada G, et al. (1999) Nutritional evaluation of table bread fortified with defatted soybean and sesame meals. Archiv Latinoameric Nutr 49, 3, 260-264.

104. Negrão CC, Mizubuti IY, Morita MC, et al. (2005) Biological evaluation of mechanically deboned chicken meat protein quality. Food Chem 90, 579-583.

105. Usydus Z, Szlinder-Richert J \& Adamczyk M (2009) Protein quality and amino acid profiles of fish products available in Poland. Food Chem 112, 139-145.

106. Jørgensen H, Brandt K \& Lauridsen C (2008) Year rather than farming system influences protein utilization and energy value of vegetables when measured in a rat model. Nutr Res 28, 866-878.

107. Ahrens S, Venkatachalam M, Mistry AM, et al. (2005) Almond (Prunus dulcis L.) protein quality. Plant Foods Hum Nutr 60, 123-128.
108. Fernandes DC, Freitas JB, Czeder LP, et al. (2010) Nutritional composition and protein value of the baru (Dipteryx alata Vog.) almond from the Brazilian Savanna. J Sci Food Agric 90, 1650-1655.

109. Ezeokonkwo CA \& Dodson WL (2004) The potential of Terminalia catappa (tropical almond) seed as a source of dietary protein. J Food Qual 27, 207-219.

110. Kannan S, Nielsen SS, Rodriguez-Burger AP, et al. (2001b) Iron and zinc bioavailability in rats fed intrinsically labeled bean and bean - rice infant weaning food products. J Agric Food Chem 49, 5063-5069.

111. Campos-Mondragón MG, De La Barca AMC, Durán-Prado A, et al. (2009) Nutritional composition of new peanut (Arachis bypogaea L.) cultivars. Grasas y Aceites 60, 2, $161-167$.

112. Ijarotimi OS \& Olopade AJ (2009) Determination of amino acid content and protein quality of complementary food produced from locally available food materials in Ondo State, Nigeria. Malaysian J Nutr 15, 87-95.

113. Malleshi NG, Hadimani NA, Chinnaswamy R, et al. (1996) Physical and nutritional qualities of extruded weaning foods containing sorghum, pearl millet, or finger millet blended with mung beans and nonfat dried milk. Plant Foods Human Nutr 49, 181-189. 